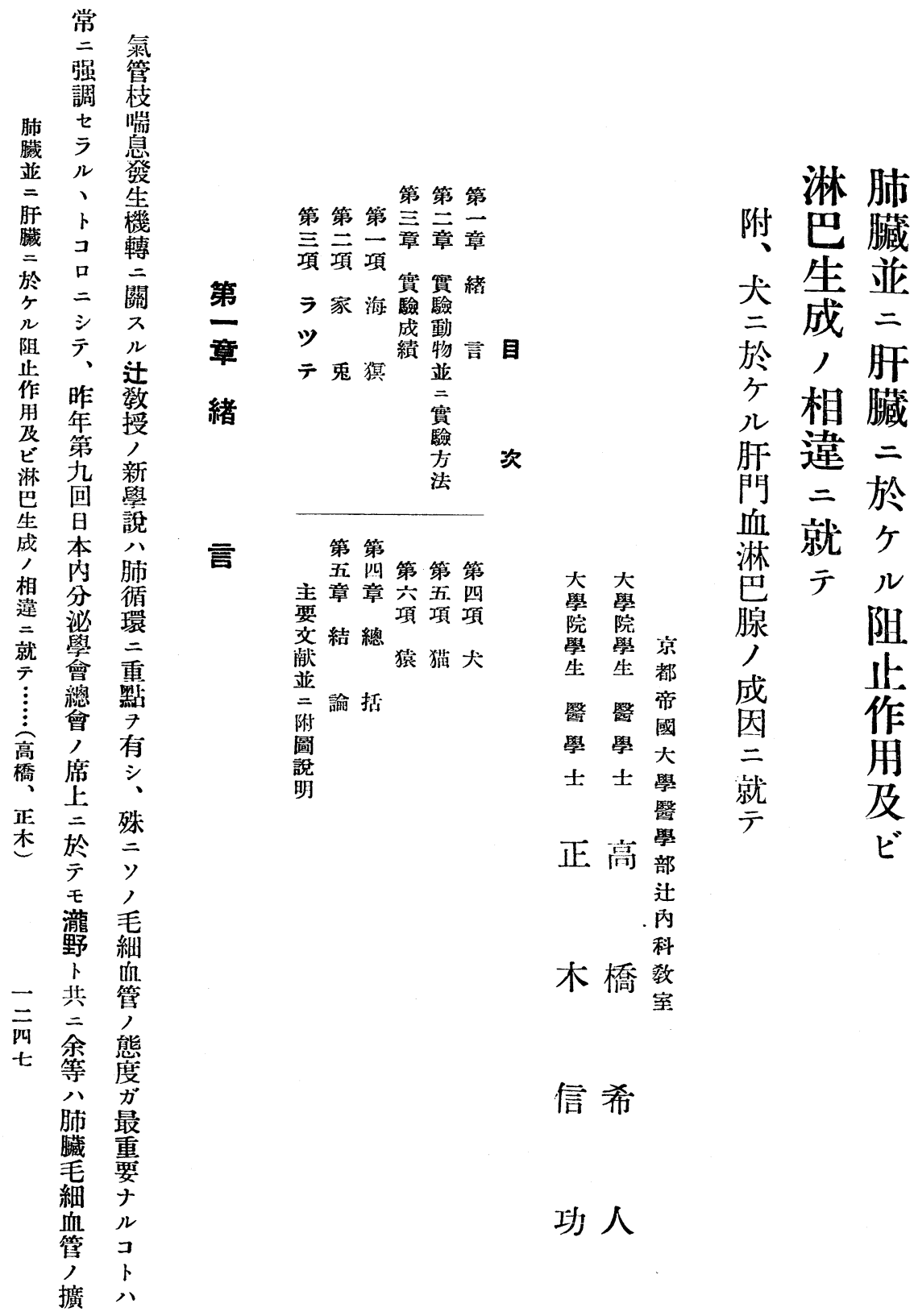




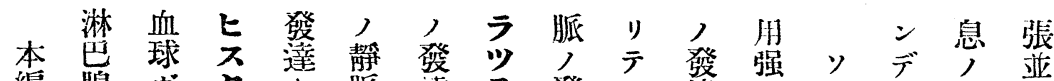
編胍召夕七脤達テ發心澾名, 毛際二

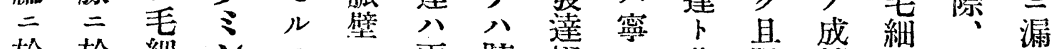

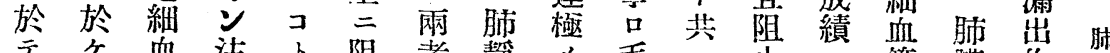

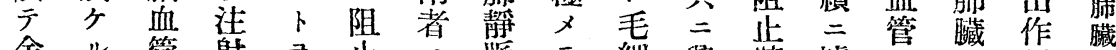
余 管 射 7 步

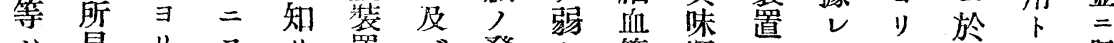

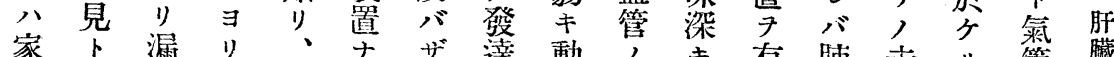

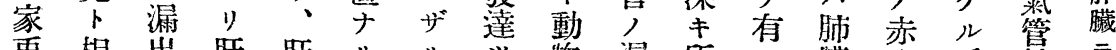

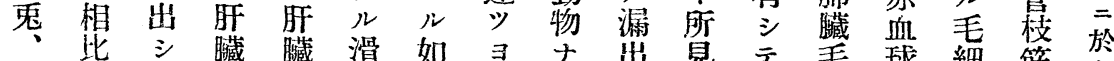

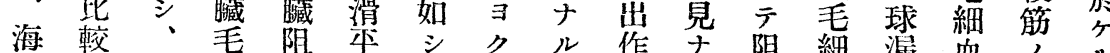

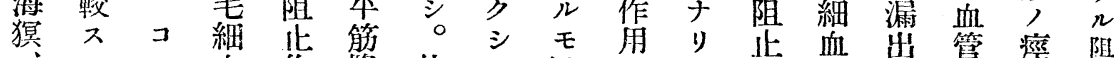
ラ

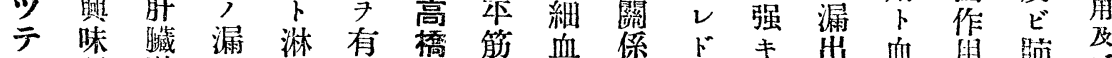
, 深 㳿出出 如 $キ 巴$ 作生儿各起, 肺肺食角出肺脈淋

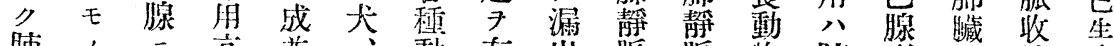

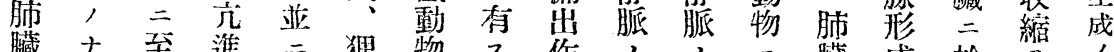

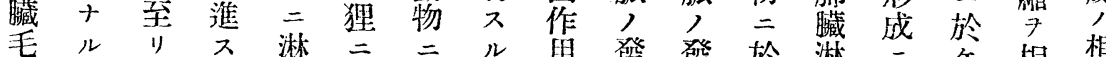

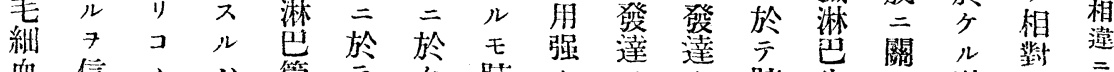
血管信

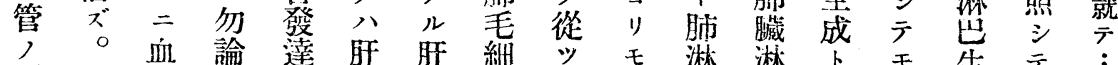

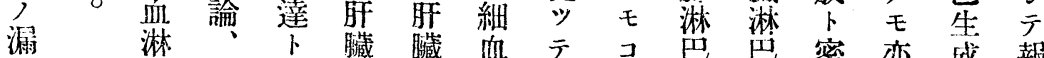

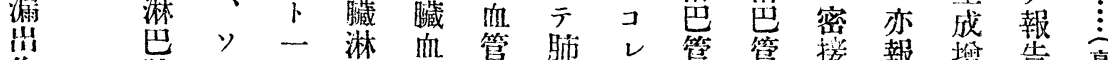

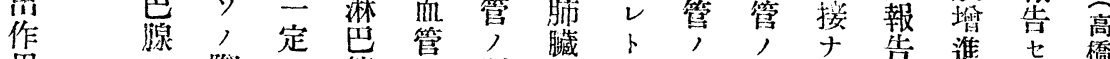

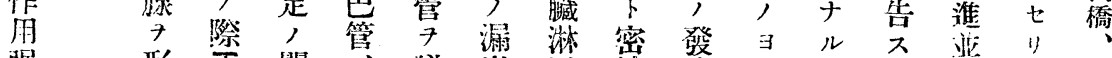
强形 正關、䛨出巴挼澾》關ル

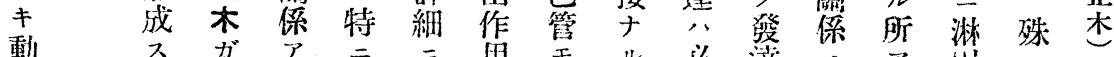

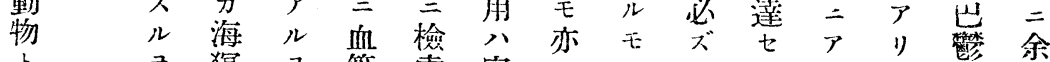

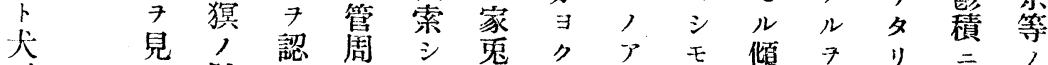

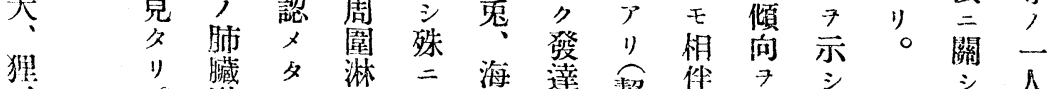

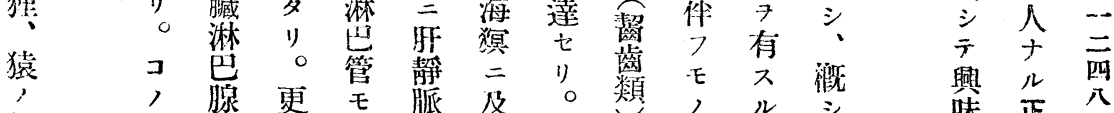

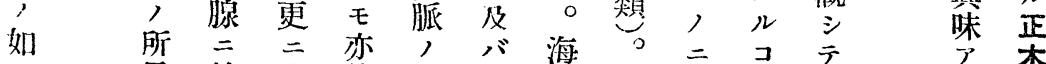

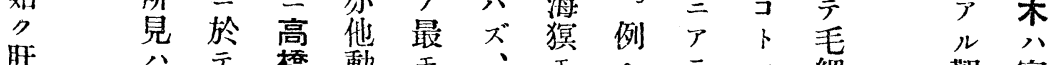
盟藏 正橋動 モ

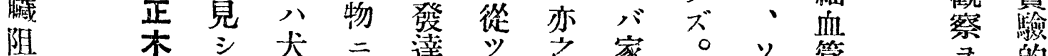

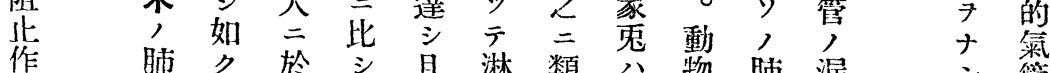

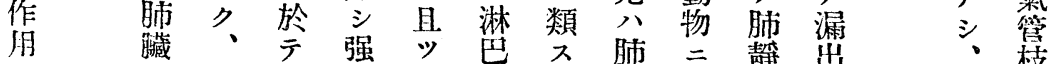

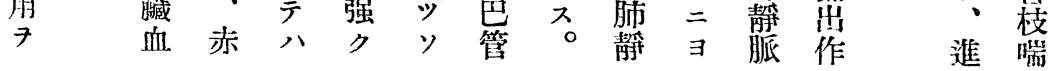




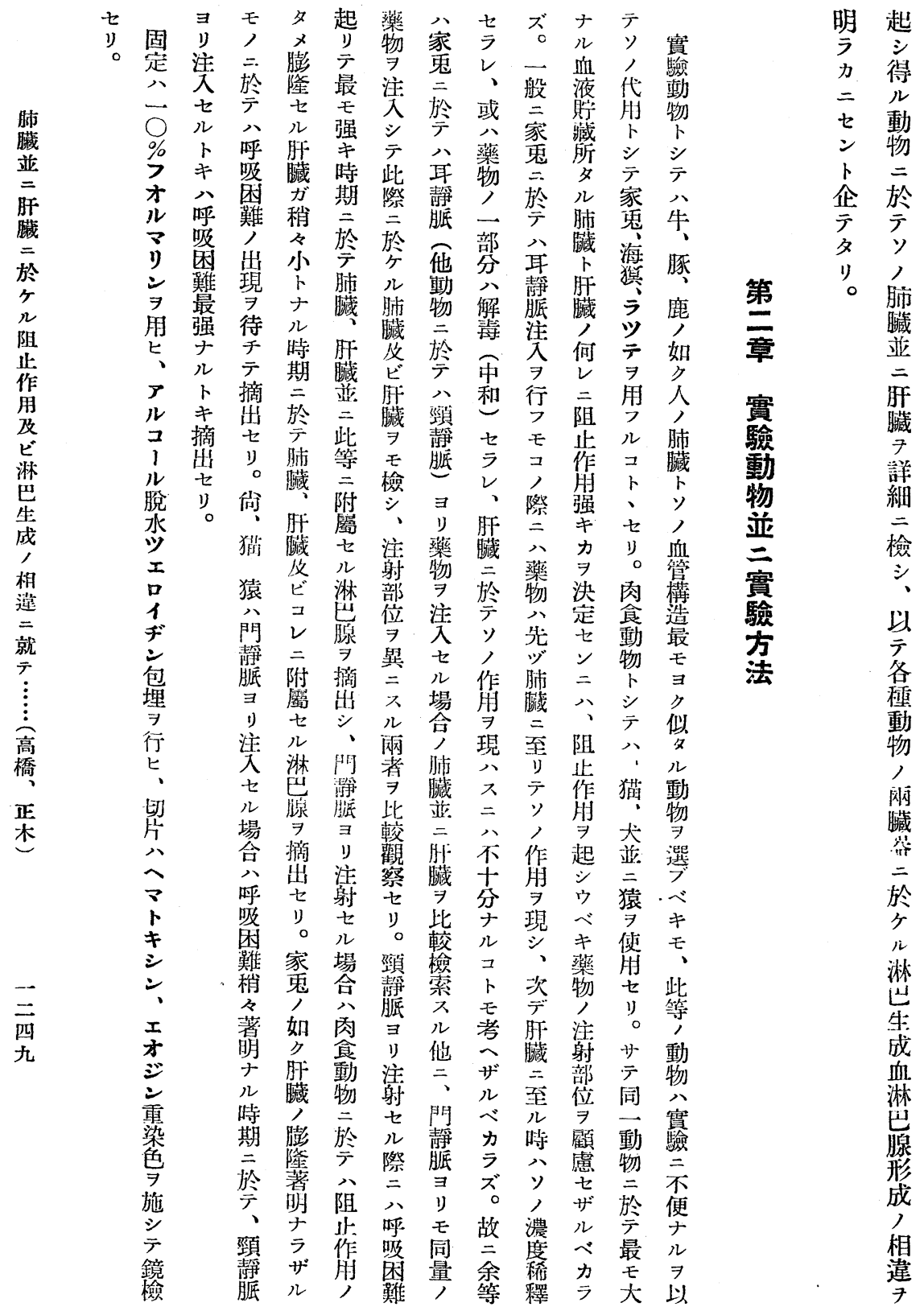




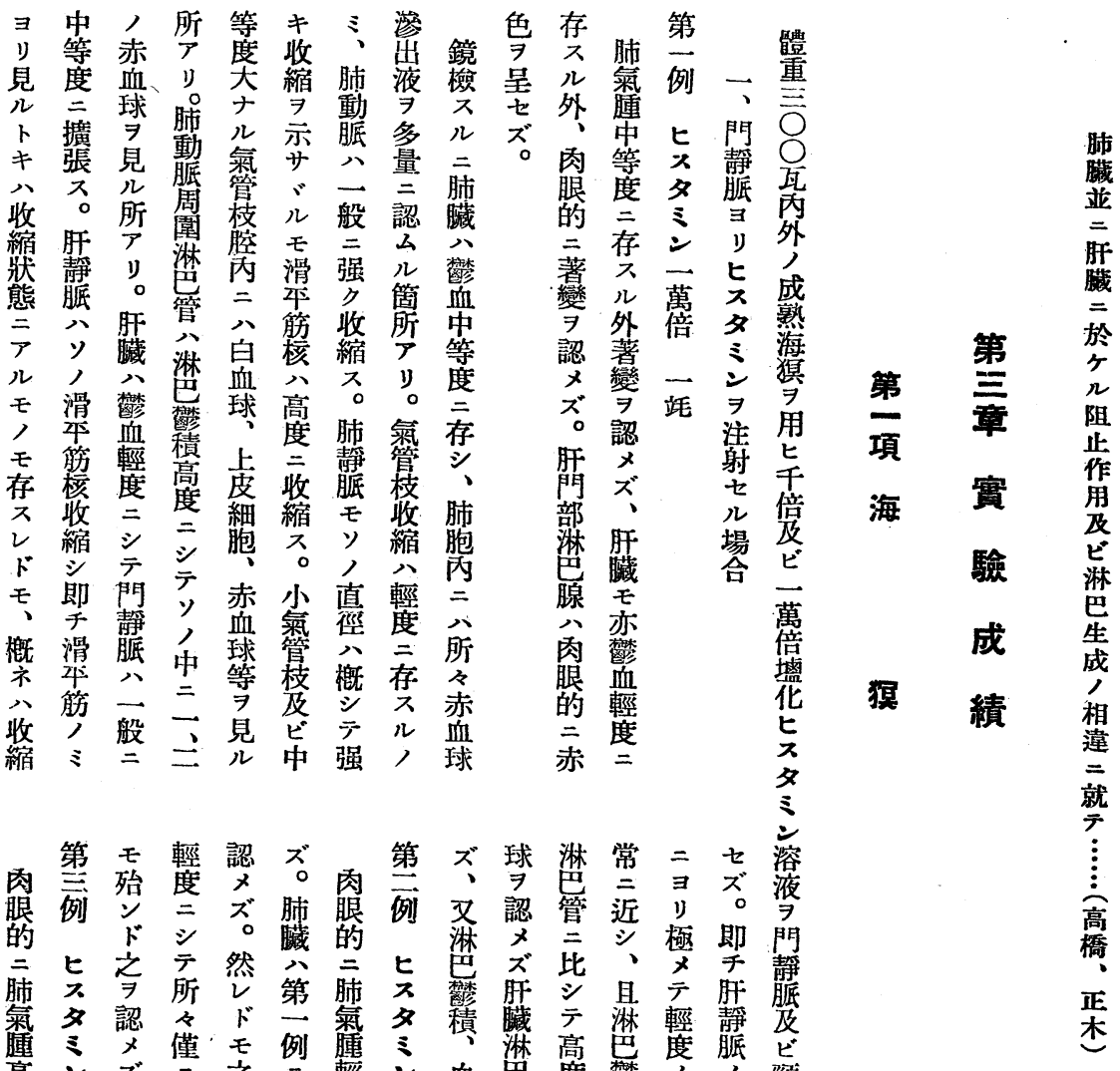
高云 ズ

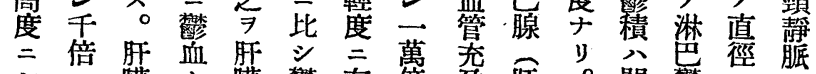

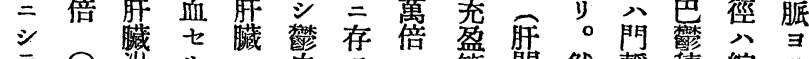

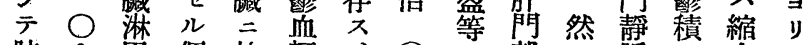

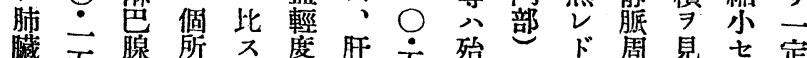
藏五俆所

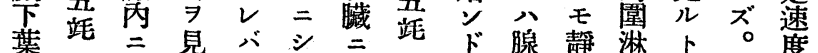

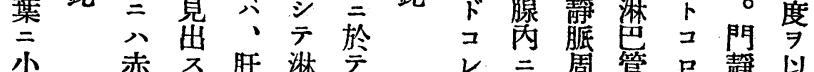

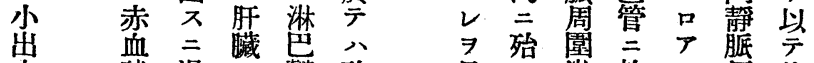

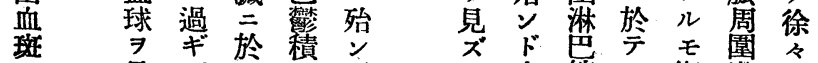
珰 見 ズ デ 於簀

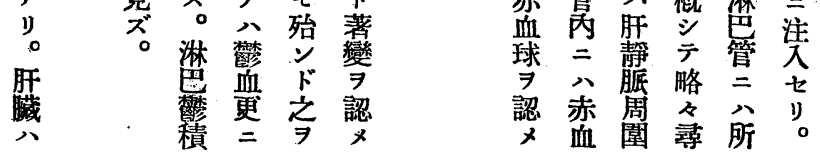




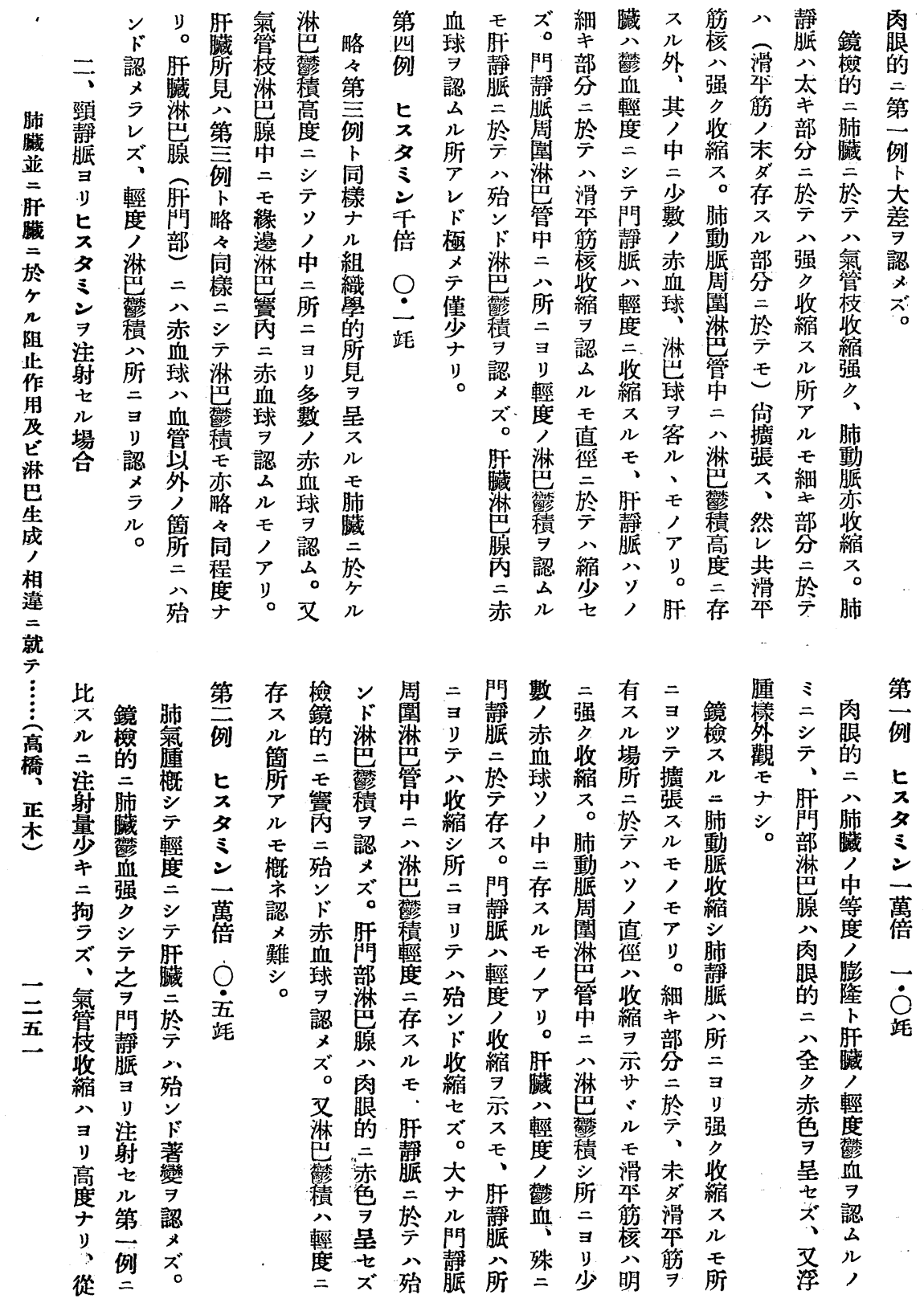




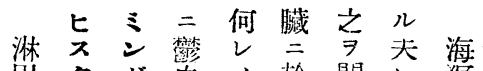

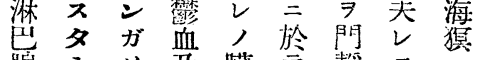

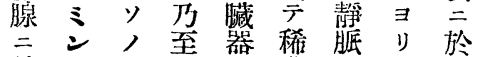

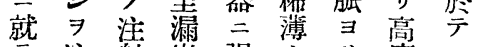

見注射出强ナ部三莨前

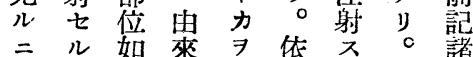

肺際何

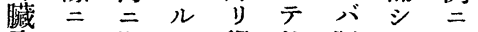

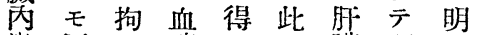

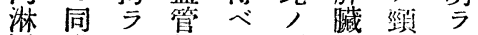

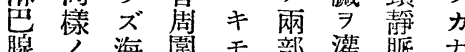

中結海淋, 位流 ${ }^{\exists}$ 胍

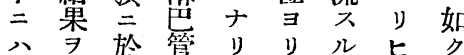

例得示中。, 七长

二夕八, 而注

ヨリ肺淋シ射夕心夕

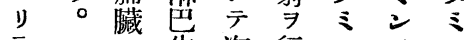

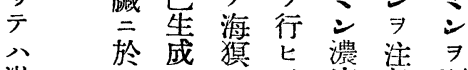

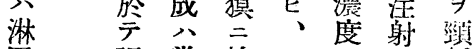

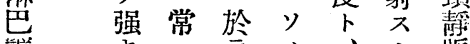

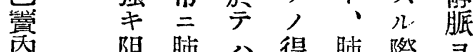

內 阻肺 公得肺際寻

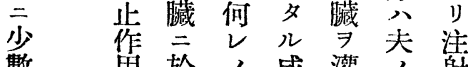

數 型於人嵗灌人射

ガ 現八脤整流

ラ ス 肝 $\exists$ リ

赤コ臓り考七文

血 $\quad 卜=$ 注察

球 $\exists$ 於射 要濃靜

$\exists$ 示ヶ ステミ度㼣

認不ルル初亡八ヨ

メモ $モ$ モ 濃肺り

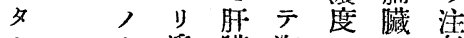

ル ナ遥臓海 $ト$ 二射

モり リ质獏八於

人。高 ビ 区六

ア又度脯於對濃王

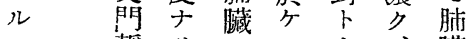

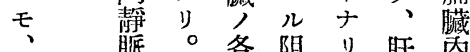

奛 ’ 即血占、臟淋

門 手管作 胀

部 ナコ角臟於形

淋 ラ人於ガ章成

出希事尔肺於稀少

腺股實儿臓テ薄肝

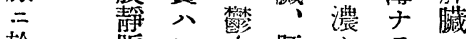

於脈七血奛クラ

小染輷

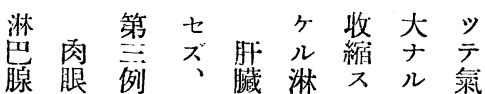

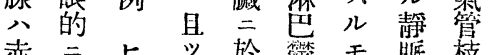

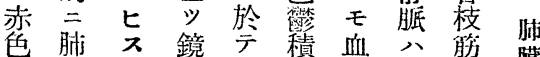

色訮

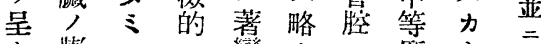

七膨之三變令公度子文

ズ隆 千舌 倍殆認第殆收, 臟

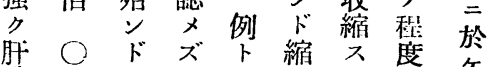

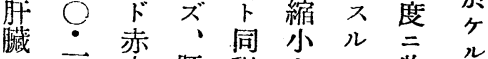

二五 血 盟程 ぜ 收 阻

导站 球臟度ザ細縮 歨

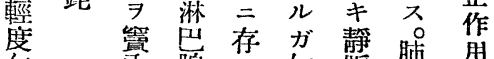

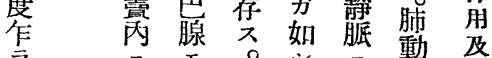

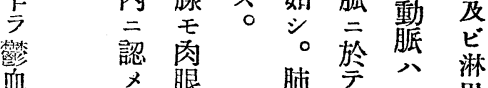

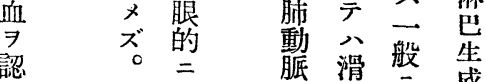

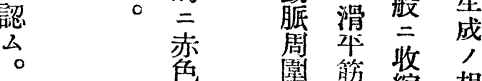

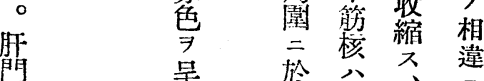

星於只、違

就

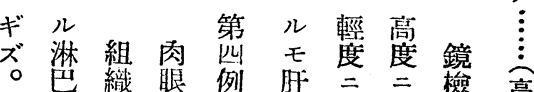

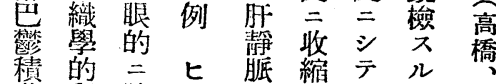

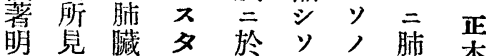

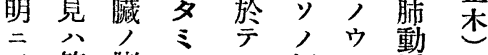

、第膨之八周千刋

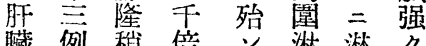

藏例稍倍弚鿄㷊ク

於略强 $\bigcirc$ 淋營球縮

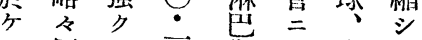

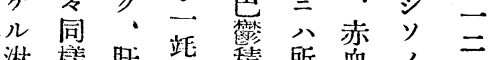

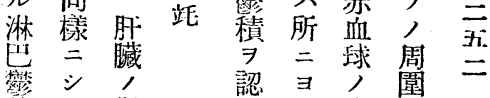

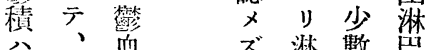

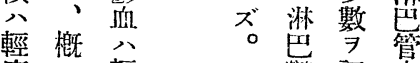

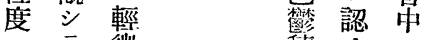

存肺微積公二

ス臟り度門 淋

儿立。於

過分公積 
第一表 海猽=於々ル肺臟並二肝臟血管周圍

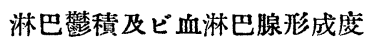

\begin{tabular}{|c|c|c|c|c|c|c|c|c|c|c|c|c|c|}
\hline 法 & & & \multicolumn{3}{|c|}{ 肺 } & \multicolumn{3}{|c|}{ 臟 } & \multicolumn{5}{|c|}{ 肝 } \\
\hline \multirow{3}{*}{$\begin{array}{l}\text { 射 } \\
\text { 部 } \\
\text { 位 }\end{array}$} & \multirow{3}{*}{$\begin{array}{l}\text { 物 } \\
\text { 番 } \\
\text { 號 }\end{array}$} & \multirow{3}{*}{$\begin{array}{c}2 \\
\text { タ } \\
\Xi \\
\dot{⿱} \\
\text { 量 } \\
\text { (c.c.) }\end{array}$} & \multirow{3}{*}{$\begin{array}{l}\text { 周氯 } \\
\text { 園 } \\
\text { 淋管 } \\
\text { 巴 } \\
\text { 管茨 }\end{array}$} & \multicolumn{2}{|c|}{ 肺動脈周圍 } & \multicolumn{2}{|c|}{ 肺靜脈周園 } & \multirow{3}{*}{\begin{tabular}{|l} 
血淋 \\
淋巴 \\
巴腺 \\
腺內 \\
形赤 \\
成血 \\
度球
\end{tabular}} & \multicolumn{2}{|c|}{ 門靜脈 周圍 } & \multicolumn{2}{|c|}{ 肝䝑脈周圍 } & \multirow{3}{*}{$\begin{array}{l}\text { 血淋 } \\
\text { 淋巴 } \\
\text { 巴腺 } \\
\text { 腺 } \\
\text { 形寻 } \\
\text { 成血 } \\
\text { 度球 }\end{array}$} \\
\hline & & & & 淋 & 己 管 & & 管 & & 淋 & 管 & 淋 & 管 & \\
\hline & & & & 太 & 細 & 太 & 細 & & 太 & 細 & 太 & 緗 & \\
\hline V.P & 1 & 萬咅 1.0 & $\div$ & + & $\div$ & $\div$ & $\div$ & 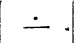 & $\dot{-}$ & - & - & - & - \\
\hline V.P & 2 & /" 0.5 & $\dot{-}$ & $\div$ & $\therefore$ & $\therefore$ & $\dot{-}$ & - & $\dot{-}$ & - & - & - & - \\
\hline V.P & 3 & 千倍 0.15 & t & H: & + & + & + & - & $\div$ & - & $\dot{-}$ & - & $\dot{-}$ \\
\hline V.P & 4 & " 0.1 & $\div$ & + & $\div$ & $\div$ & $\div$ & $\dot{-}$ & $\dot{-}$ & - & - & - & - \\
\hline V.J & 1 & 萬倍 1.0 & + & $H$ & $\div$ & $\div$ & $\div$ & $\dot{-}$ & $\dot{-}$ & - & $\dot{-}$ & - & - \\
\hline V.J & 2 & " 0.5 & + & + & $\div$ & $\div$ & $\div$ & $\dot{-}$ & $\dot{-}$ & - & - & - & - \\
\hline V.J & 3 & 千倍 0.15 & $t$ & H & + & $\div$ & $\div$ & $\dot{-}$ & $\dot{-}$ & - & - & - & - \\
\hline V.J & 4 & " 0.1 & + & H & $\div$ & $\div$ & $\div$ & $\dot{-}$ & $\dot{-}$ & - & - & - & - \\
\hline
\end{tabular}

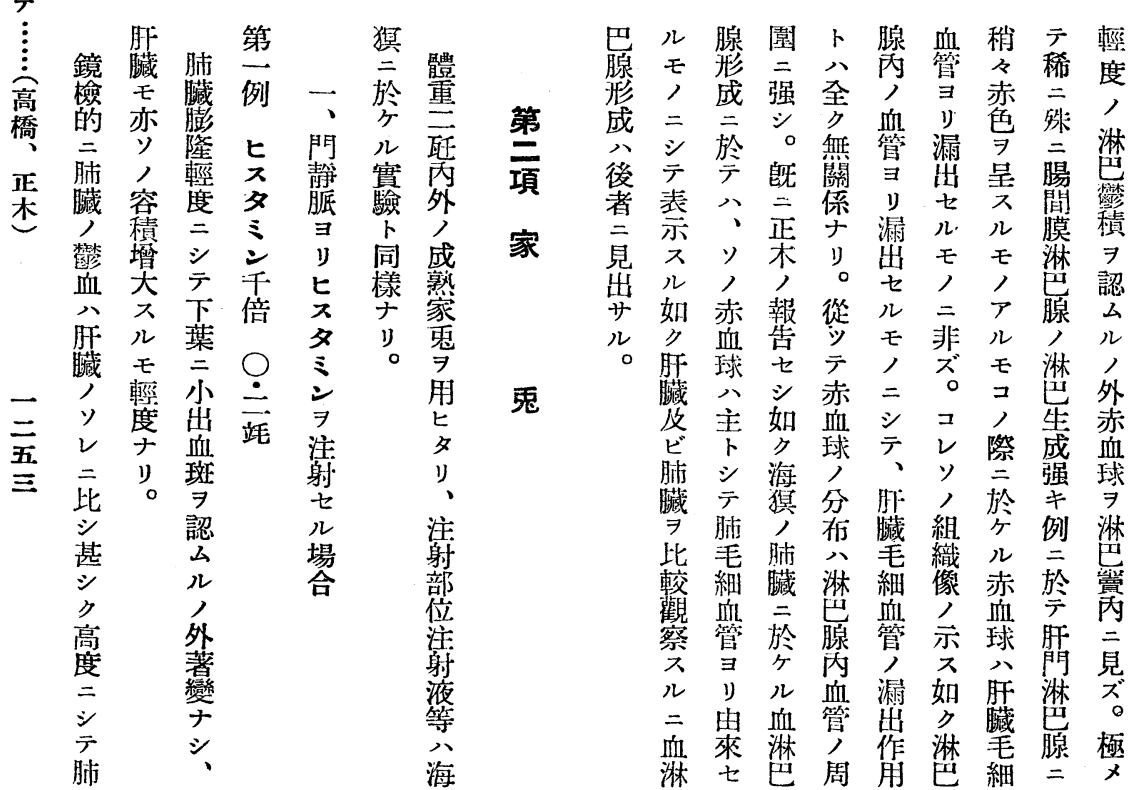




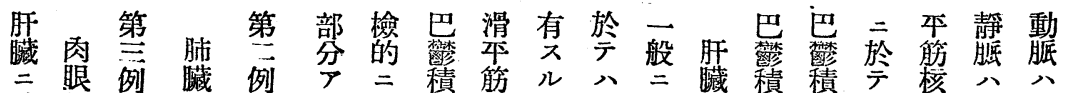
於的列 藏 例 ア

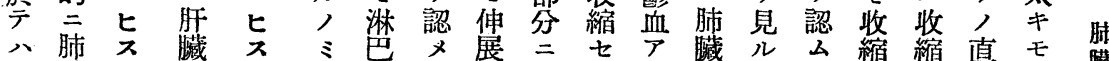
輕藏 女

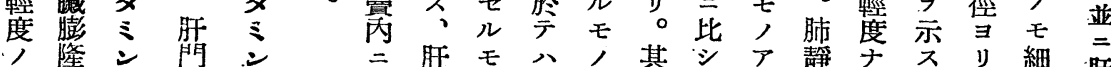

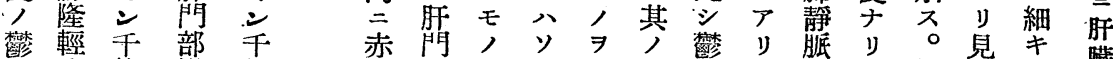

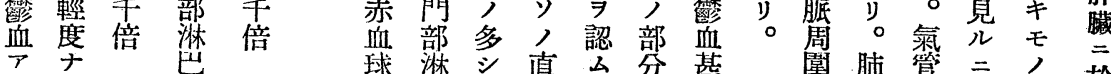

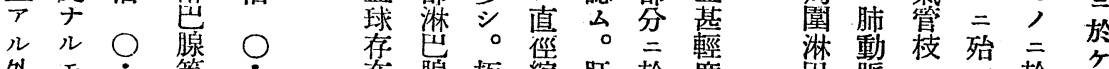

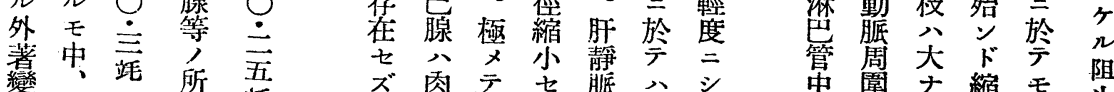

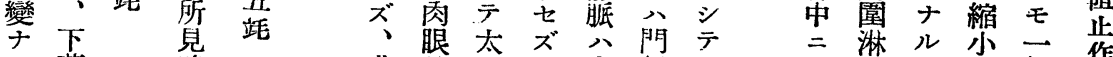

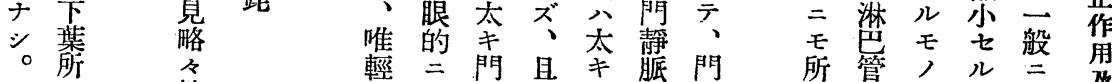
々 第

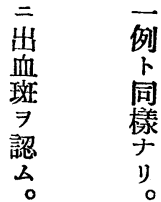

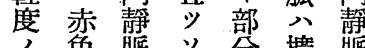

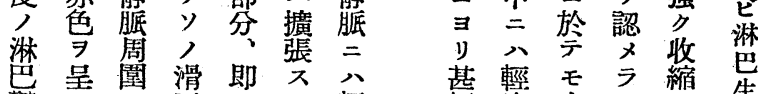

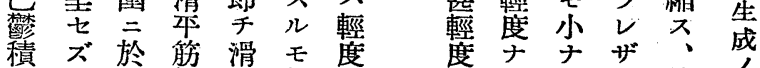
見又宁管等部ル ル 鏡 淋 ビ

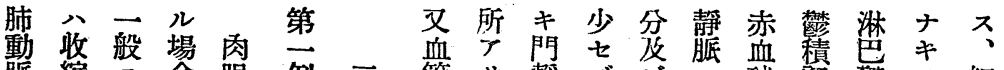

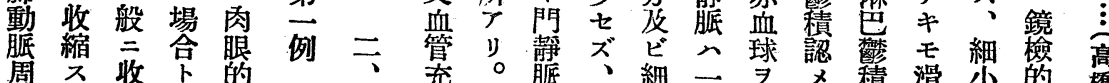

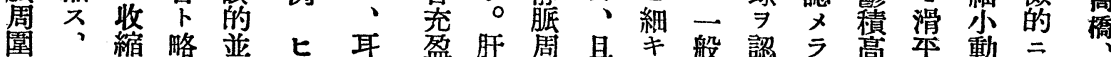

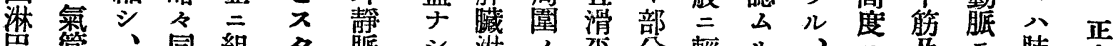

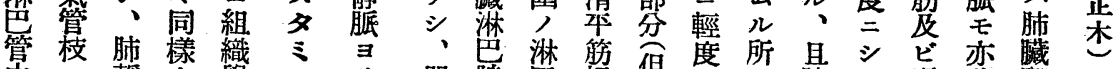

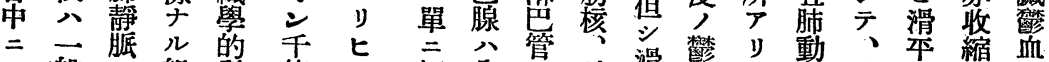
公般公质的乎

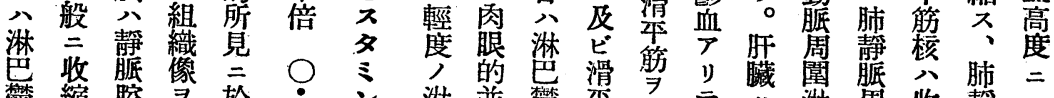

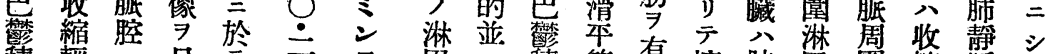

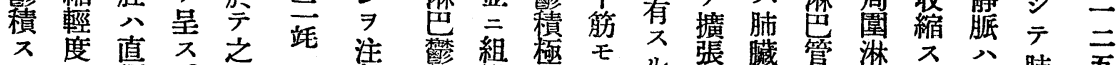

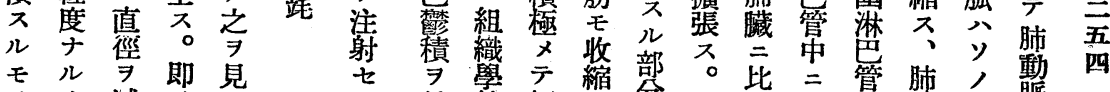
○減于ル見的輕七分肝必公動直脈 中殆ぜ肺二場

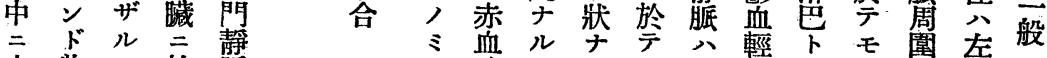

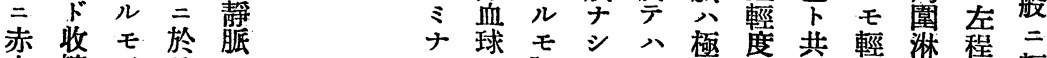
血縮、宁 $\exists$ 球 $\Rightarrow$ 滑 八リ 八示本肺注 殆 斗筋 動 射

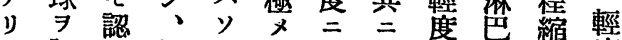
。認 極, テ シ 極怎管想度 ズラ ル

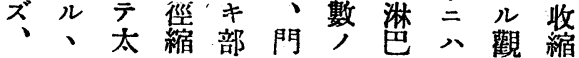




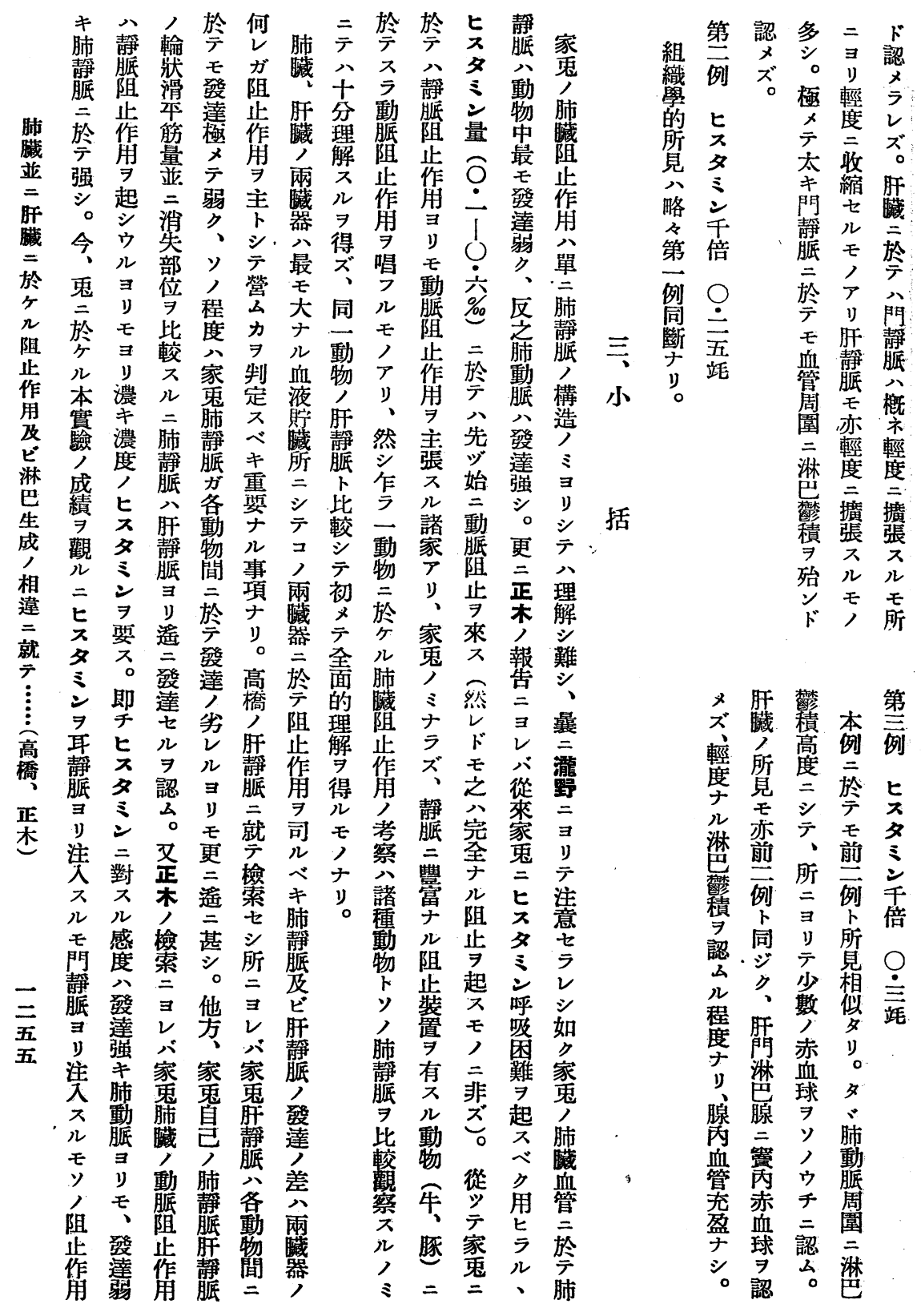


第二表 家鬼二於ヶル肺臟並二肝臟血管周園 淋巴㱉積及ビ血淋巴腺形成度

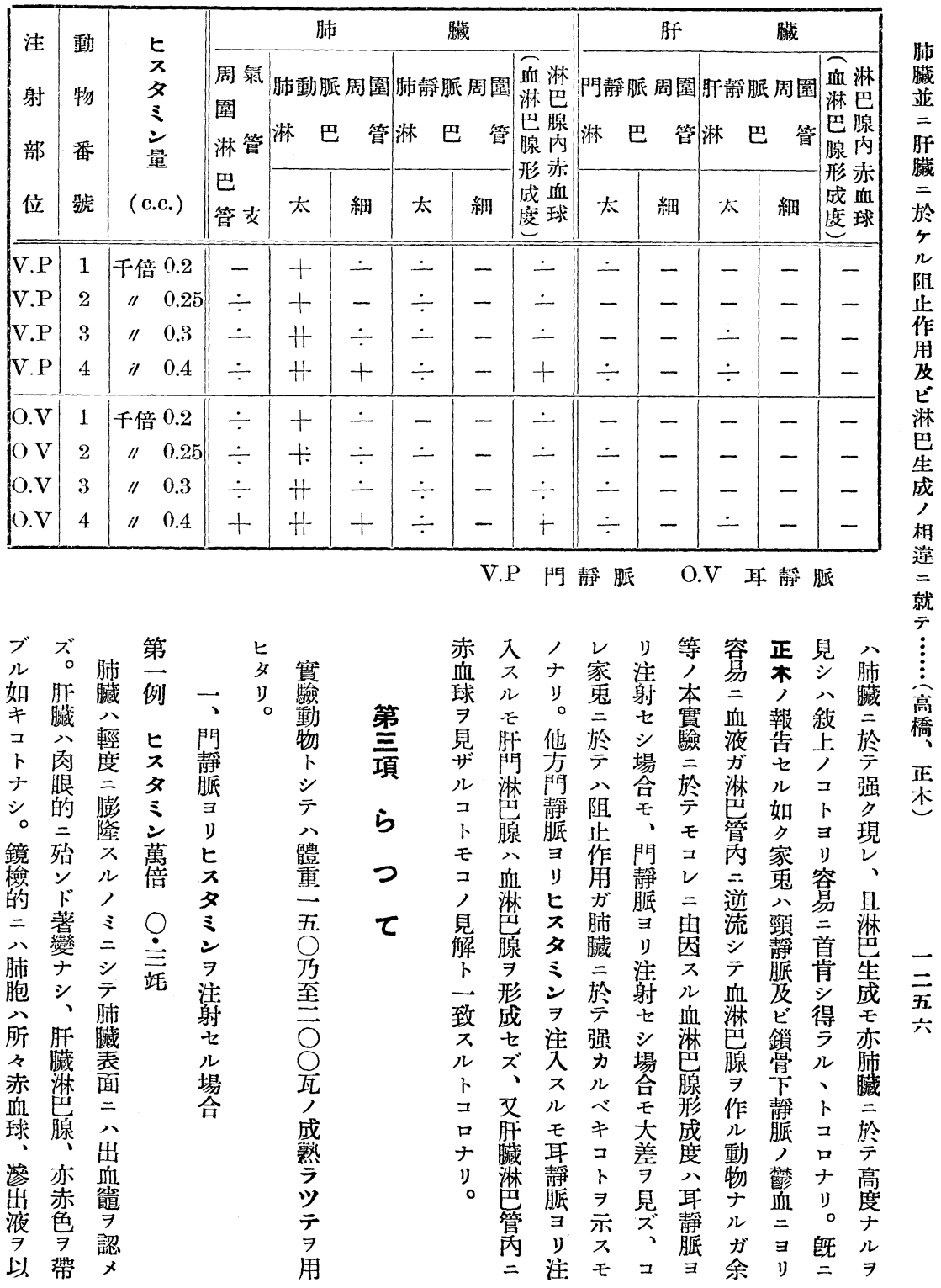




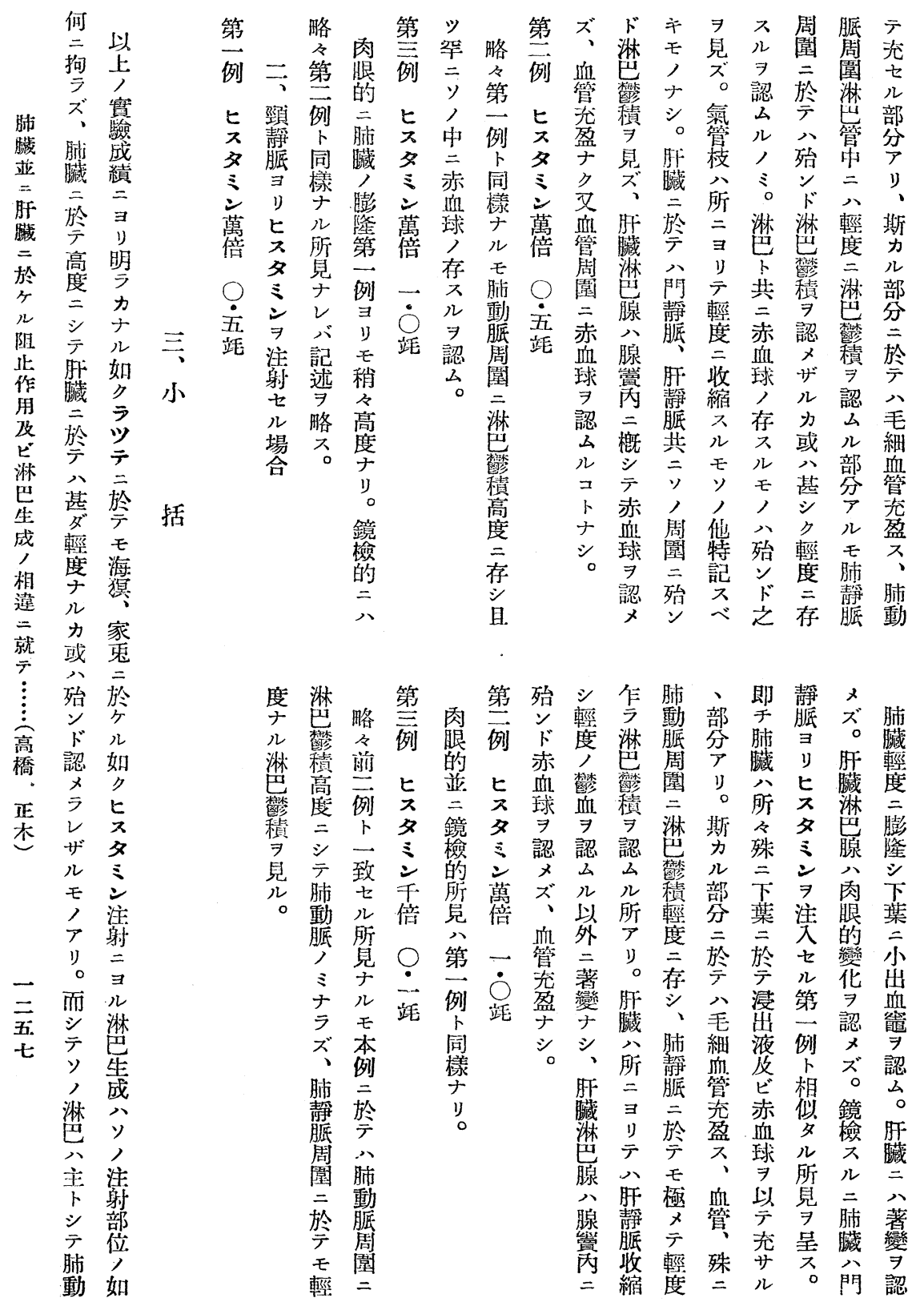


第三表 ラツテニ於ヶル肺臟並 $=$ 肝臟血管周圍

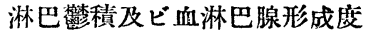

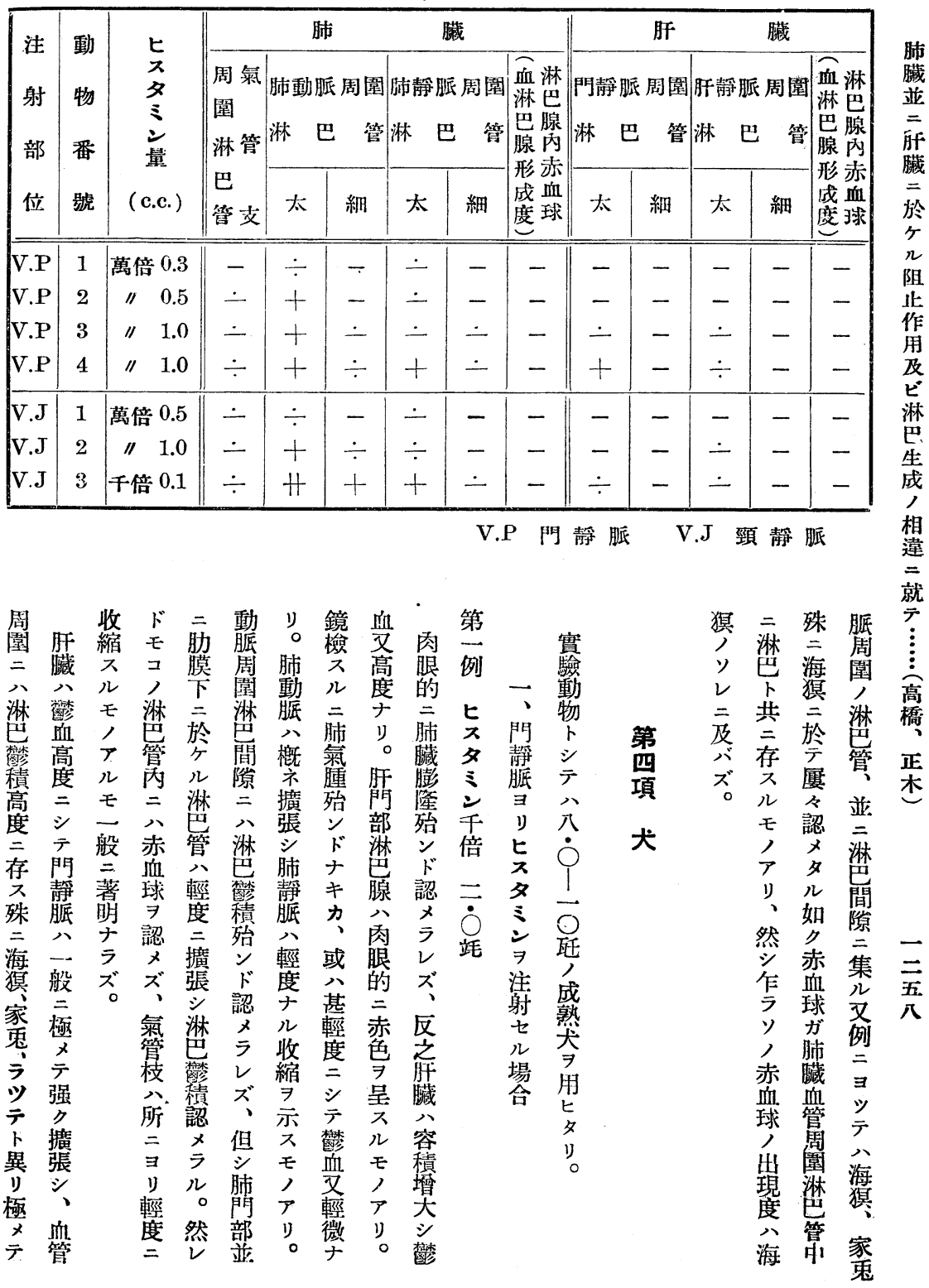




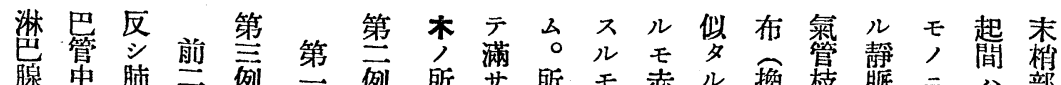
腺 虫 肺 例 例 例 所モ赤

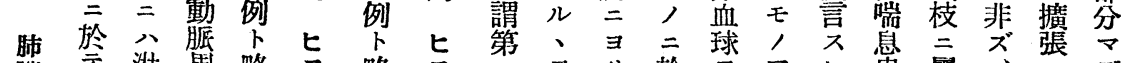
臓テ淋居略ス 略 ス

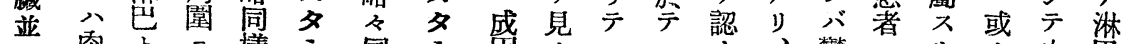

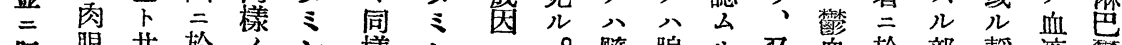

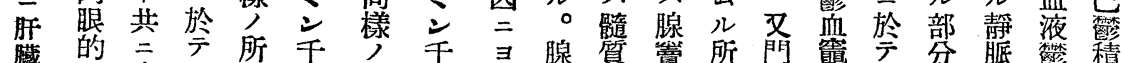

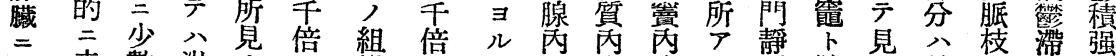

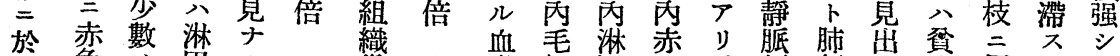

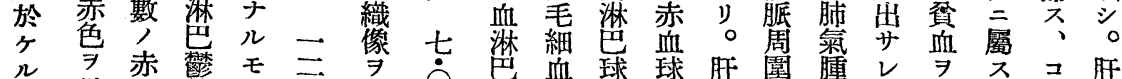
呈血精

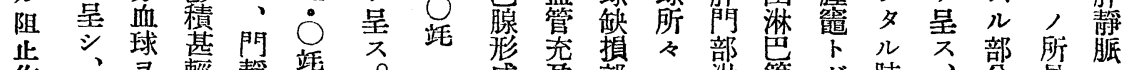
作、 $\rightarrow$ 輕靜 站

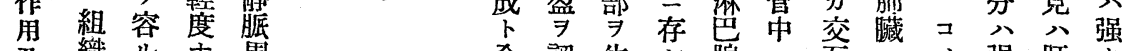
及織ルナ周 ビ學、リ園

淋的千。淋

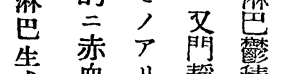

成血り。靜 頪

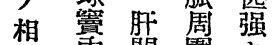
全認生言腺二互三, 强肝名

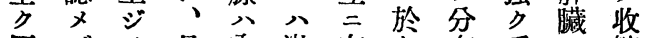

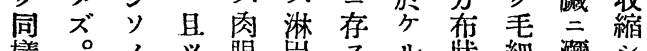

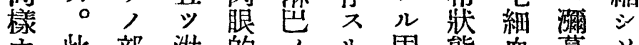
于此部淋的人 ル固態血㯰り ○, 分森赤外 $三$ 有分管性,

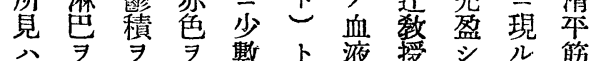

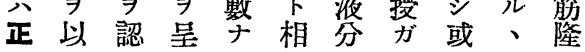

違 內 部潾

就

$\bar{\tau}$

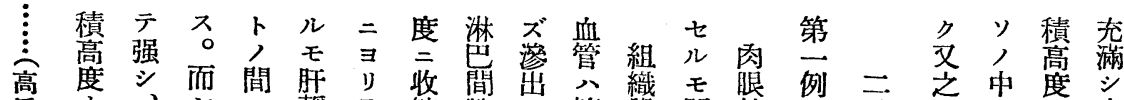

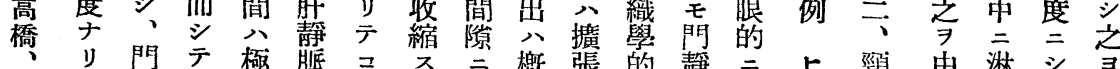
正。靜り 極脈 コ

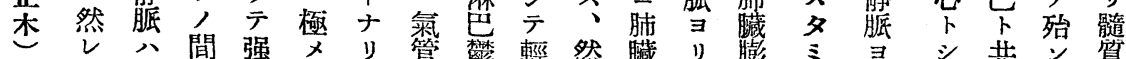
ド二 二 方 、枝積度

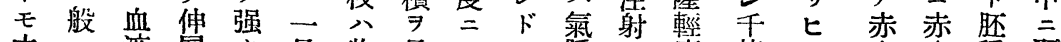

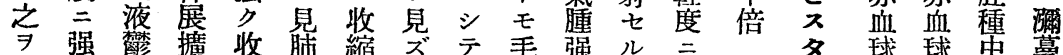

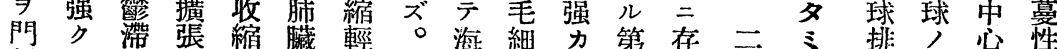

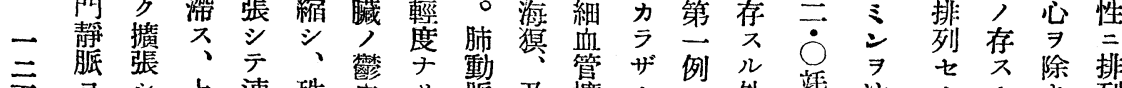

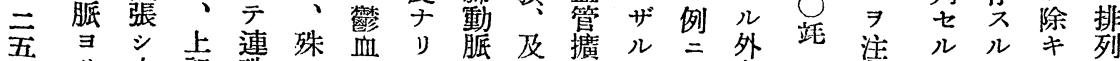

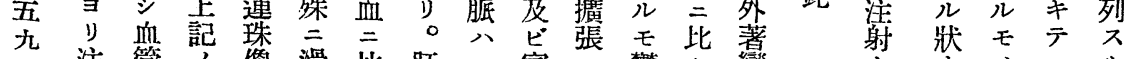

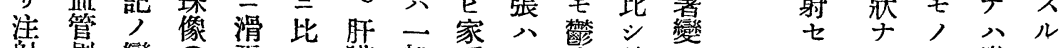

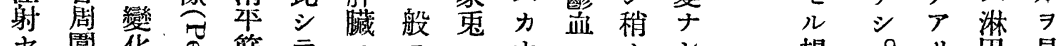

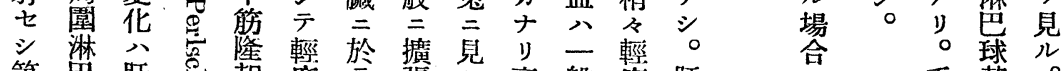

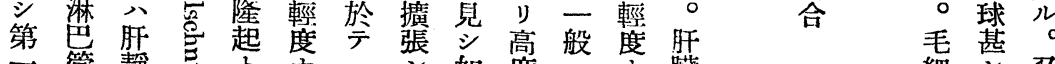

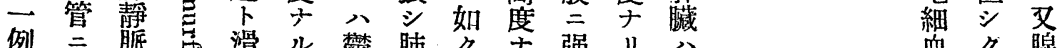

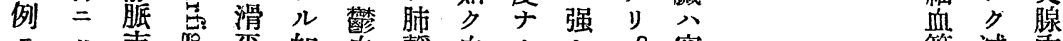

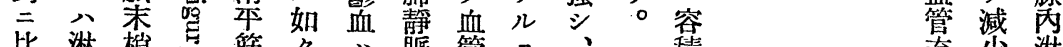

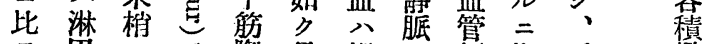

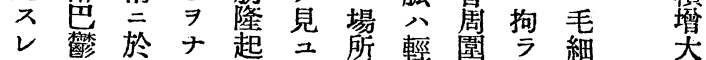
赏临㷊 


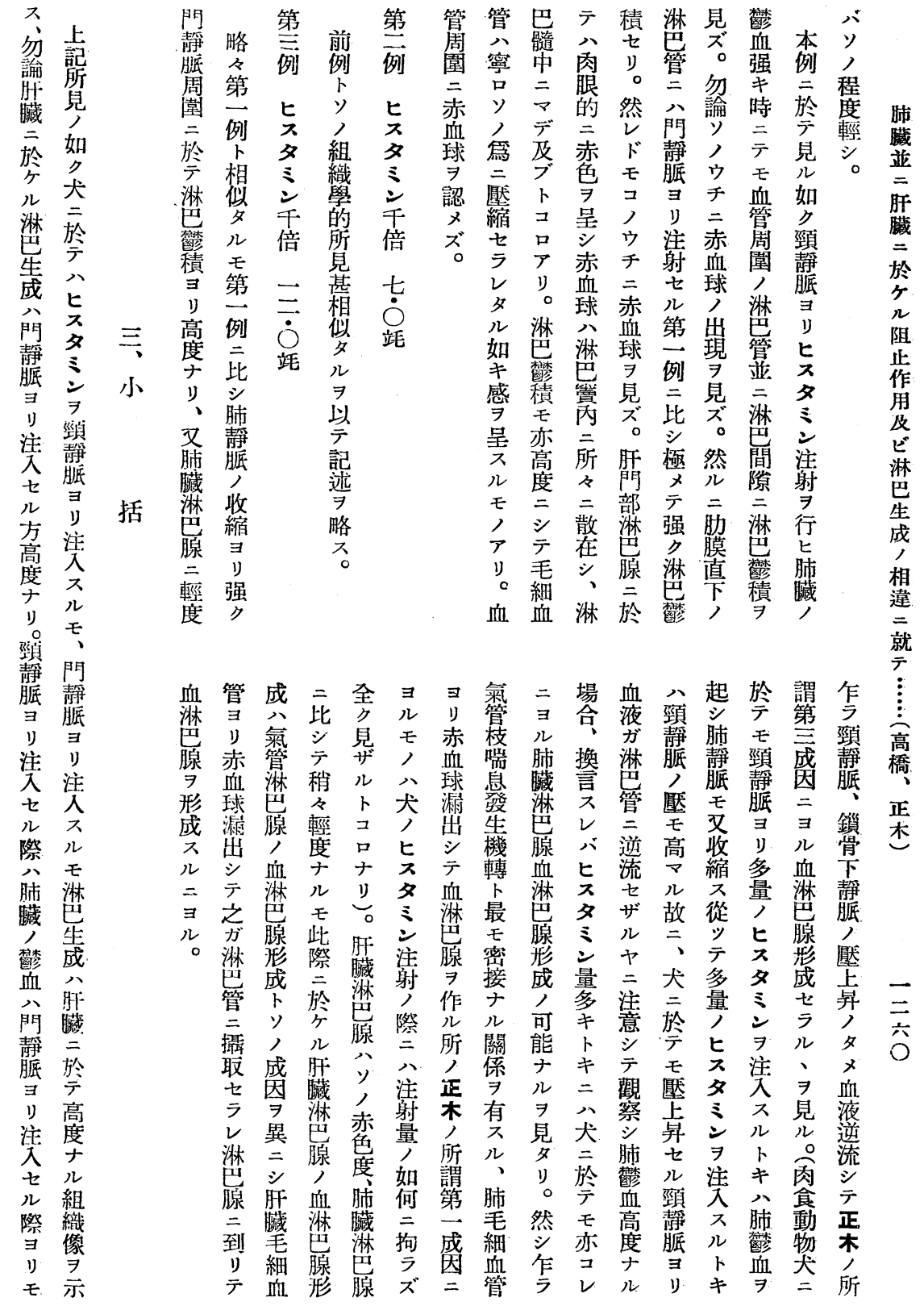


第四表 犬二於ケル肺臟並 $=$ 肝臟血管周圍

淋巴稂積及ビ血淋巴腺形成度

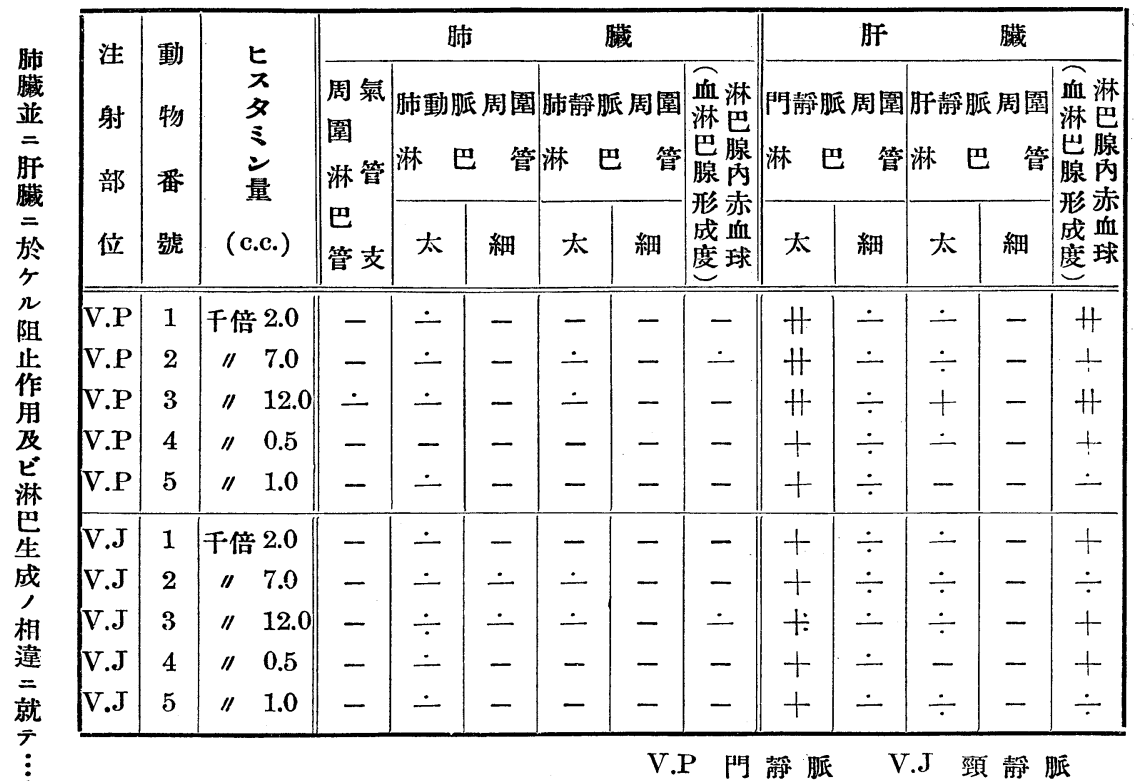

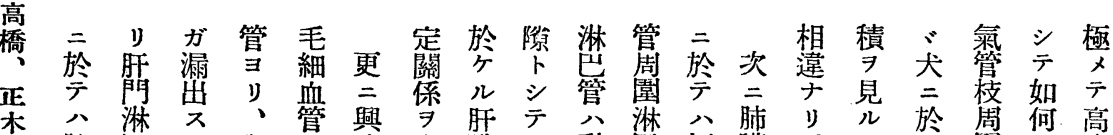

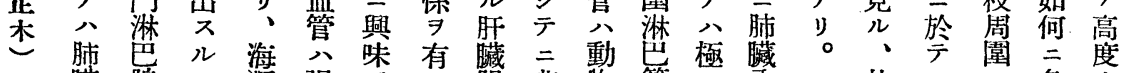

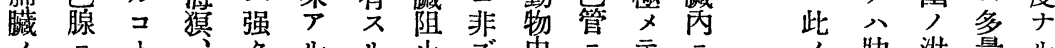

淋至上、只ル此虫

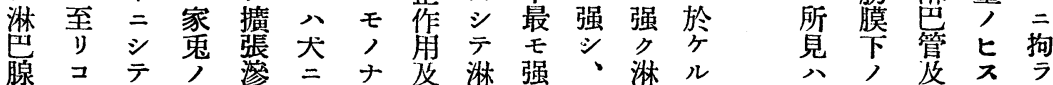

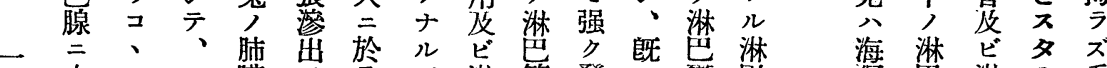

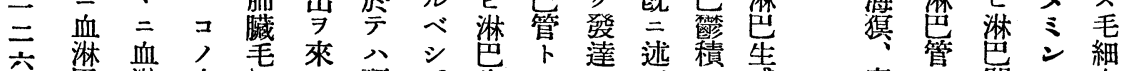

六湘血 埜毛來 細

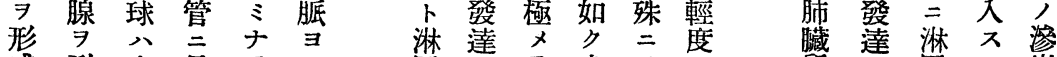

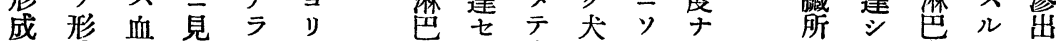

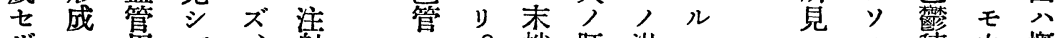

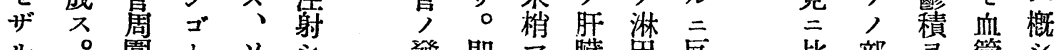

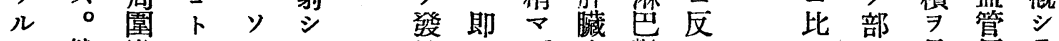

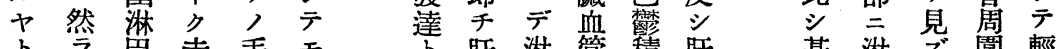

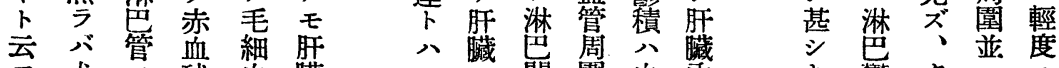

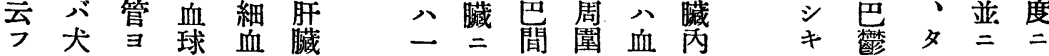




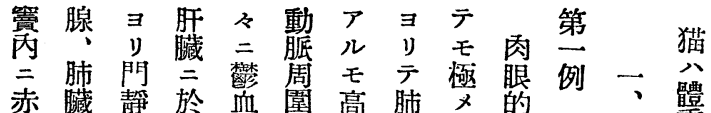

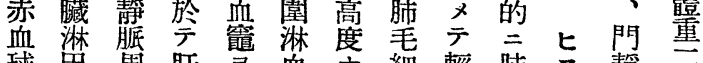

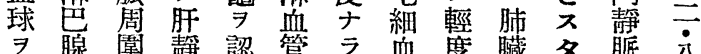

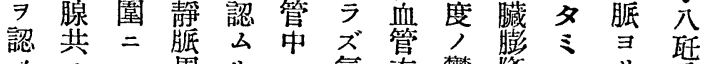

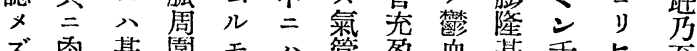

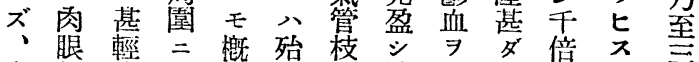

血的度 冭占收肺認輕文

管

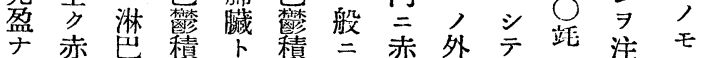

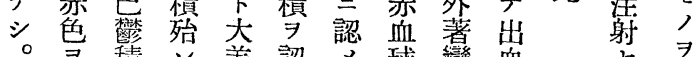

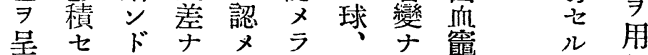

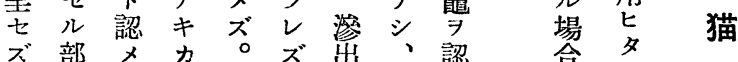

ズ部 メ カ 或肝

又り

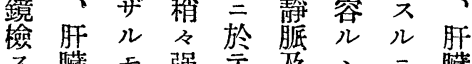

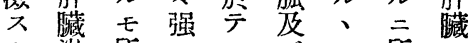

モ漤所シ。毛 ビモ所立

明云枝度 $、$ 然動 勳第

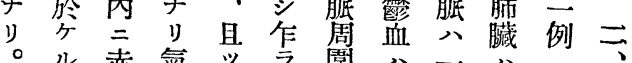

淋血管 コ肺子 家般肉七頸

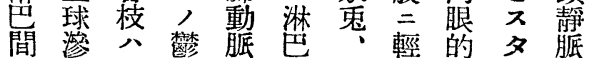

隙 出收積, 管 海》三ミ引

, 液縮八刀分璂收殆之リ

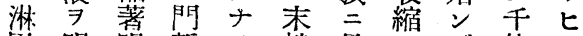

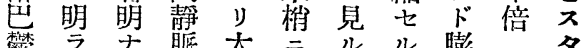

樍力ラ当於如狀隆六主

公ズり部テ》態七゙竓シ

肺認、注分八高悲

; 又又又华度六、

上ズ海セ淋焦ナリ輕㴬

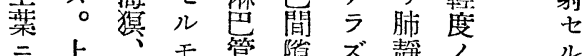

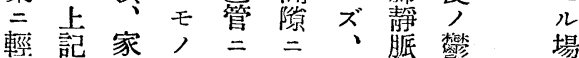

度人兔二八淋血壬血

三太三比輕管亦存

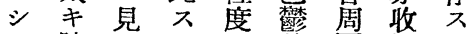

テ肺南 レニ積園縮 ル

下動如 バ淋㴅コスノ

葉脤方稍芭認ト、感

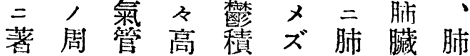

ノ決鬼 三

リ 志於

- 血尔於

淋儿兵

巴程 モ

腺高頸 臟

蔗嶅 並

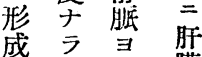

ヨザリ 臟

見儿多臬於

ル正皇ケ

八木七元

注分阻

自所名作

હ第シ 用

キ $\exists$ 及

䙿威望 淋

$=$ 二

テリバ成

換 血 '

言㷊肺 相

$\checkmark$ 腺 血 =

㕣形 二 就

犬七

ラ

於儿、頸 高

八然脤

肺 流 正:

贜怎䚂 杰

細 肺 骨

血臟 下

管 毛 挈

$\exists$ 細 脈

赤益 厴

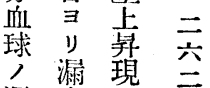

洮出 。

七儿從

ザ赤 ッ

ル血 テ

ב球 犬

$r==$

示寻於

ス

モ从家 


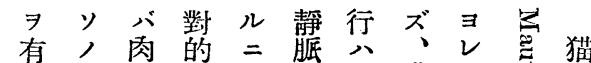

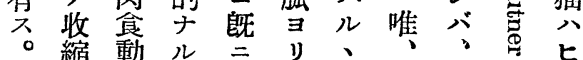
即牀物意瀧滑草猫巨原

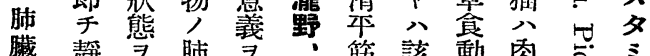

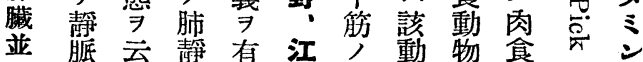
奣壁々 胍 せ崎發物二動) =

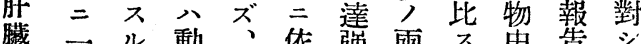

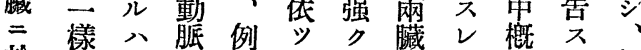
於三穻三人テ遥器 バシル極 ケ排當近 バ報气, 肝テ所メ

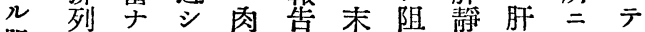
阻七亏動食七梢止膝靜寻敏 止 ズズ质動 ラマ作公脤レ感 作シ、八物レデ用㮐人公

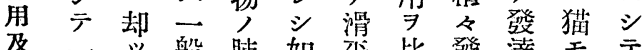
及一曲般肺如华比發達モテ ビ 定テ三靜方筋較達弱犬極 淋, 肺靜脈肺見七七》的 巴間静脈人静出ザルソ於量 生隔胍 $\exists$ 滑胍将儿如, 不

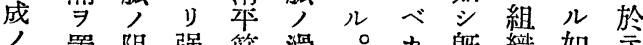

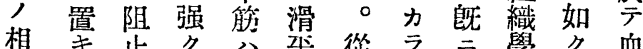

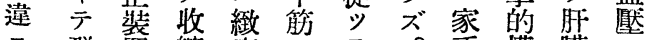
就壁置縮 密公此。鬼構藏人 テ シ シ 得排, 點然就造於降 $\vdots$ ○テル 列排 $ノ=$ テ

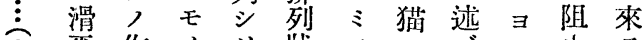
高平作ノソ牀 $コ=$ ふり止 橋算用ナ了態り於音觀作

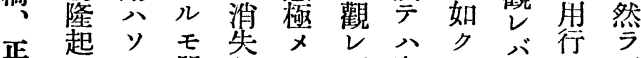

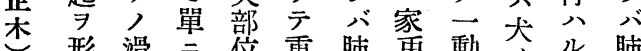
成望動壬要臓三物如上臟 不筋腯草子三於三云卜

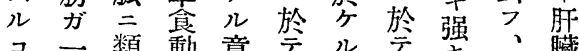
卜般似物䇅强肺何阻然

\section{一 二 動セ卜}

二意胍儿大有阻璄血㤰最

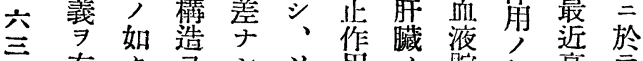

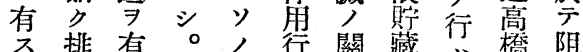
ス排有又滑少關藏监橋阻 此セルソ平 $ル ト ニ ル$ 肝作 點ザコ人筋、異於、㱖角 $\exists ル ト$ 構沙 ゙リテモ脈行

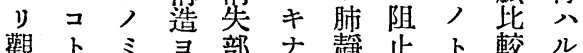

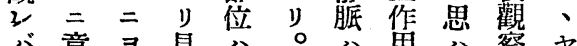

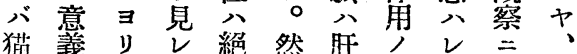

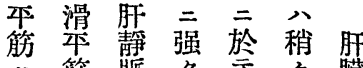

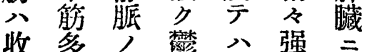

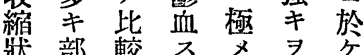
態 嵒的。咨

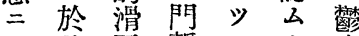
テテ年靜 $ヨ ル$ 血 リ八筋前》所槩 。犬少八擴 $>$ 場 然二キ場誓り所 於 部 所 シ $0=$ 乍方公二、肝 $\exists$ 二ラル滑 ヨ中靜り 血程尔り心脈

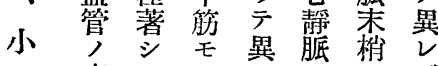
直 $キ$ ソ $\Rightarrow$, 鲻收, ド中既王 分縮筋モ心 概 $\Rightarrow$ 核 $一$ 滑藏 括 シ 認毛般 シ 平三

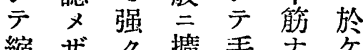
小ル伸留細キ ぞ滑展 ス

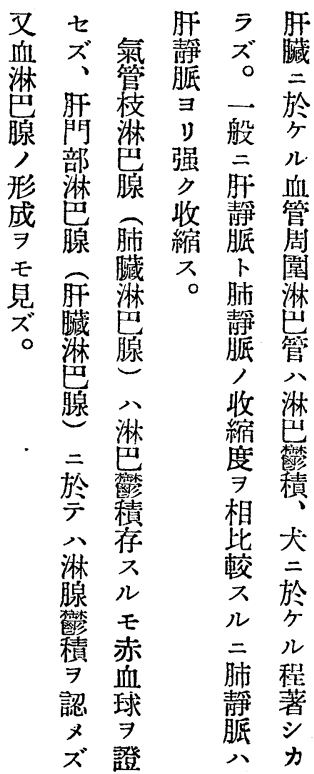


第五表 猫二於ヶル肺臟並 $=$ 肝臟血管周圍 淋巴秕積及ビ血淋巴腺形成度

\begin{tabular}{|c|c|c|c|c|c|c|c|c|c|c|c|c|c|}
\hline \multirow{4}{*}{$\begin{array}{l}\text { 注 } \\
\text { 射 } \\
\text { 部 } \\
\text { 位 }\end{array}$} & \multirow{4}{*}{$\begin{array}{l}\text { 動 } \\
\text { 物 } \\
\text { 番 } \\
\text { 號 }\end{array}$} & \multirow{4}{*}{$\begin{array}{c}ヒ \\
\pi \\
3 \\
\vdots \\
亡 \\
\text { 量 } \\
\text { (c.c.) }\end{array}$} & \multicolumn{3}{|c|}{ 肺 } & \multicolumn{3}{|c|}{ 臟 } & \multicolumn{3}{|c|}{ 肝 } & \multicolumn{2}{|l|}{ 臟 } \\
\hline & & & \multirow{3}{*}{$\begin{array}{l}\text { 周氣 } \\
\text { 園 } \\
\text { 淋管 } \\
\text { 巴 } \\
\text { 管支 }\end{array}$} & \multicolumn{2}{|c|}{ 肺動脈周圍 } & \multicolumn{2}{|c|}{ 肺静脈 周圍 } & \multirow{3}{*}{$\begin{array}{l}\text { 血淋 } \\
\text { 淋巴 } \\
\text { 巴腺 } \\
\text { 腺 } \\
\text { 形赤 } \\
\text { 威血 } \\
\text { 度球 }\end{array}$} & \multicolumn{2}{|c|}{ 門靜脈周圍 } & \multicolumn{2}{|c|}{ 肝靜脈 周園 } & \multirow{3}{*}{$\begin{array}{l}\text { 血淋 } \\
\text { 㷊巴腺 } \\
\text { 腺 } \\
\text { 形赤 } \\
\text { 盛球 } \\
\text { 度球 }\end{array}$} \\
\hline & & & & \multicolumn{2}{|l|}{ 淋 } & \multicolumn{2}{|c|}{ 淋 巴 管 } & & \multicolumn{2}{|c|}{ 淋 巴 管 } & \multicolumn{2}{|c|}{ 巴淋 巴管 } & \\
\hline & & & & 太 & 細 & 太 & 細 & & 太 & 細 & 太 & 細 & \\
\hline V.P & 1. & 千倍 5.0 & $\dot{-}$ & - & - & - & - & - & $\div$ & $\div$ & - & - & $\dot{-}$ \\
\hline V.P & 2 & " 7.0 & $\dot{-}$ & $\dot{-}$ & - & - & - & - & $\dot{-}$ & $\dot{-}$ & - & - & - \\
\hline V.P & 3 & " 5.0 & $\div$ & - & - & - & - & - & $\div$ & $\div$ & - & - & - \\
\hline V.J & 1 & 千倍 6.0 & $\dot{-}$ & $\div$ & $\dot{-}$ & $\div$ & - & - & $\div$ & - & - & - & - \\
\hline V.J & 2 & /" 7.0 & $\dot{-}$ & $\div$ & $\dot{-}$ & $\div$ & - & - & $\div$ & - & - & - & - \\
\hline V.J & 3 & /" 5.0 & - & $\div$ & $\dot{-}$ & $\div$ & - & - & $\dot{-}$ & - & - & - & - \\
\hline
\end{tabular}

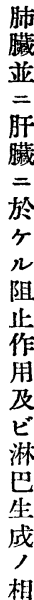
相

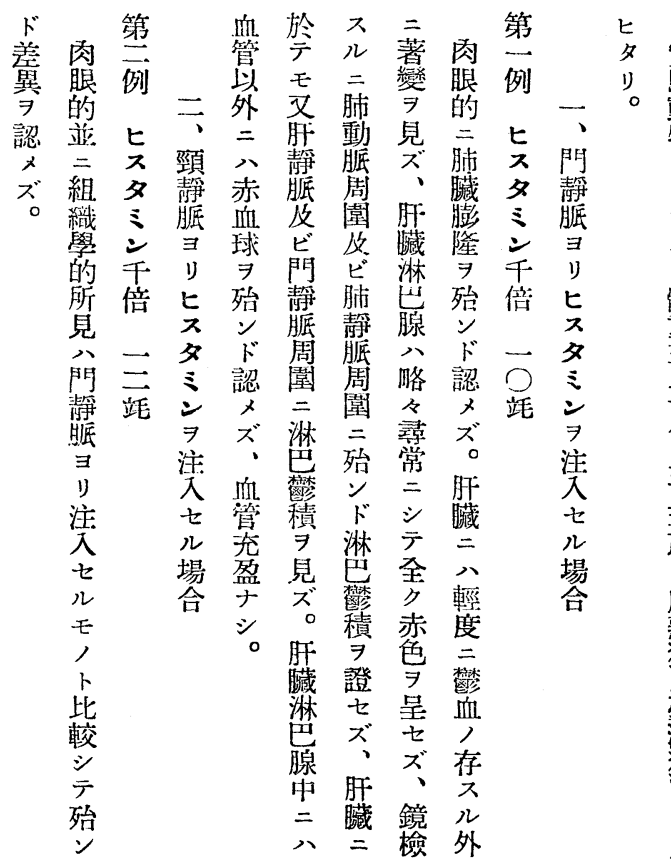

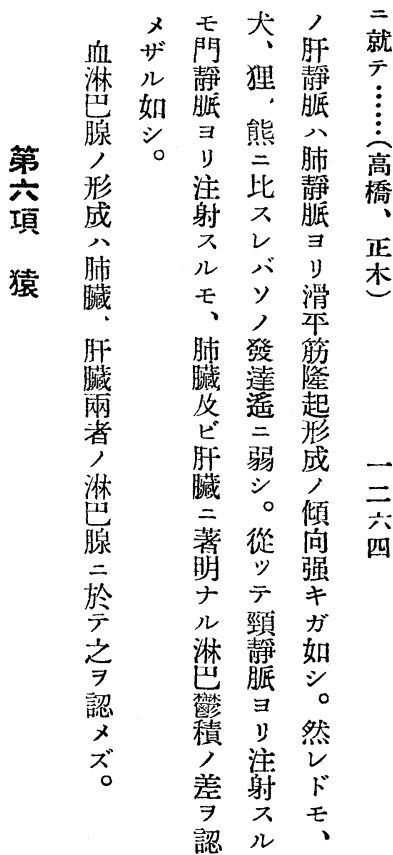


第六表 猿ニ於ケル肺臟並 $=$ 肝臟血管周圍

淋巴罍積及ビ血淋巴腺形成度

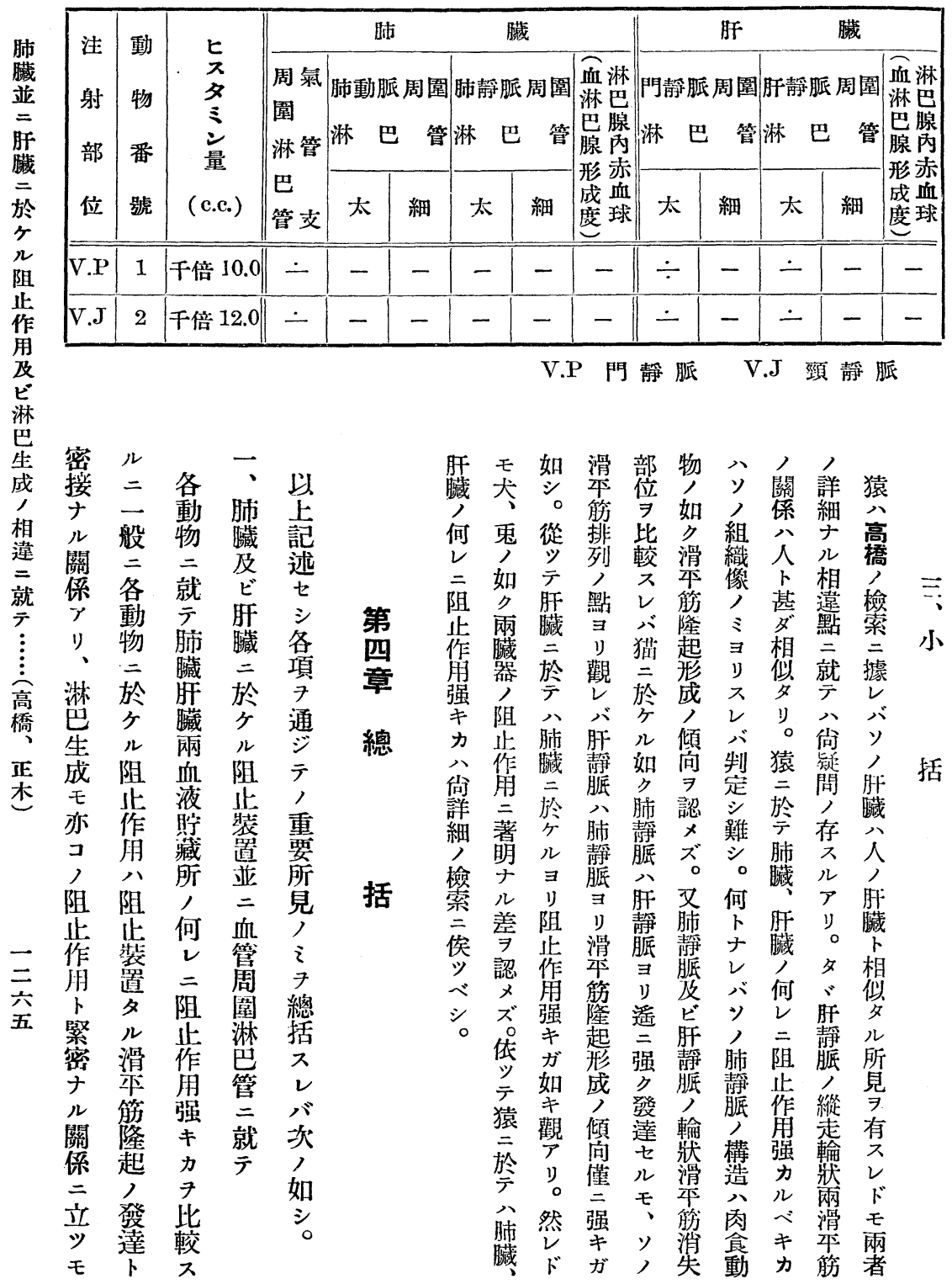




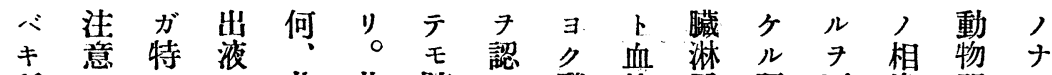
所 ス 少此此肺么 發管热胿要違間レ

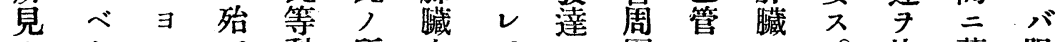

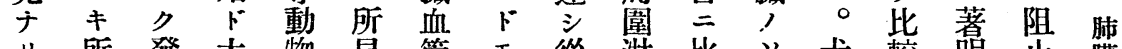
り所發大物見管 モ 從澿比り大較奛止臟

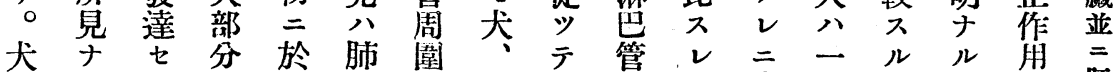

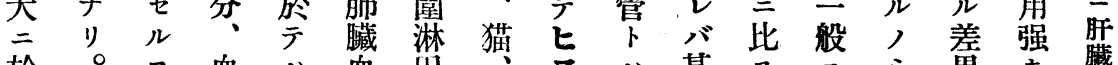
於 0 血八血出、 $心$ 基 テ 热

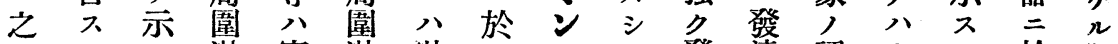
二レス 淋實淋淋テノモ發達認ナモモ於阻 反バモ出驗出巴心如共達極么 小ノテ步

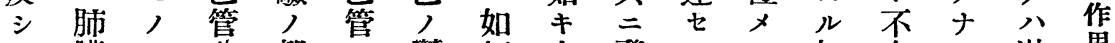

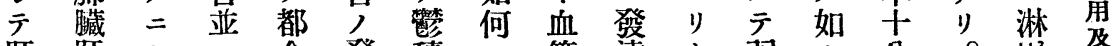

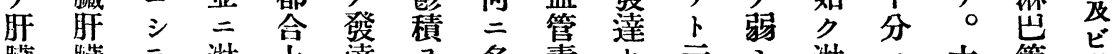

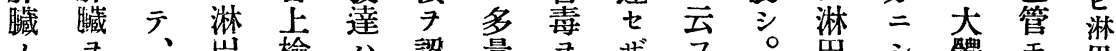

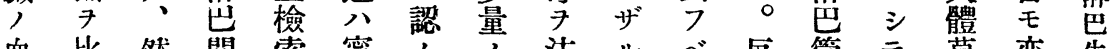
血比然間 索寧么ノ注ルざ反管テ草亦生

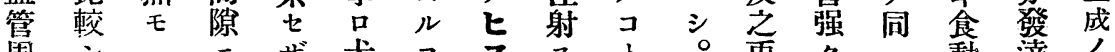

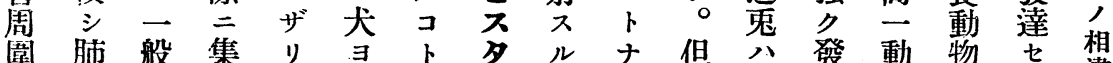
園 肺 般 集 リ

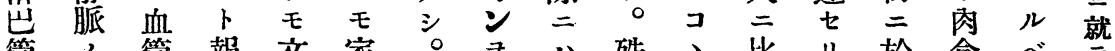
管 人 管 報 交 家。7 八殊、比り於食べテ

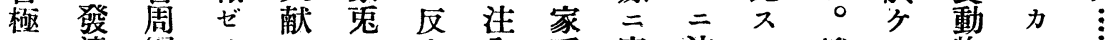

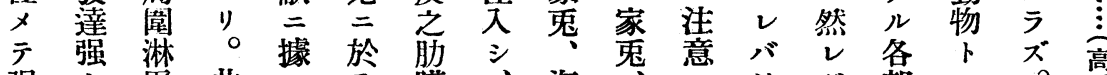

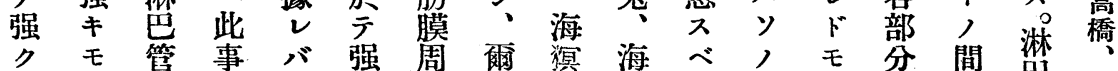

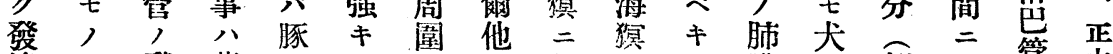

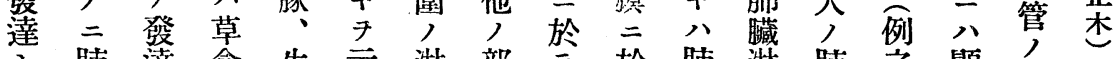

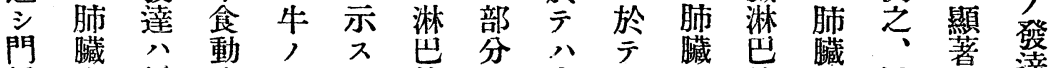

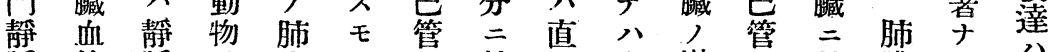

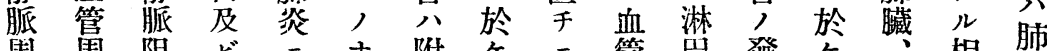

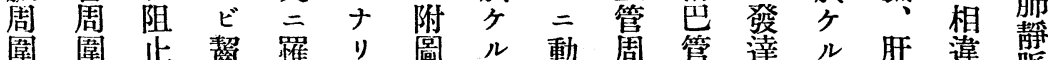

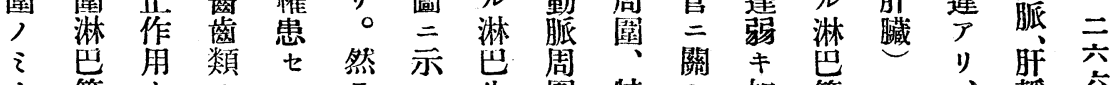
ナ管卡, 心 ラ人密肺モバ如成淋二テキう, 淋然脈

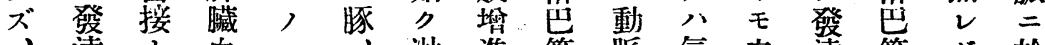

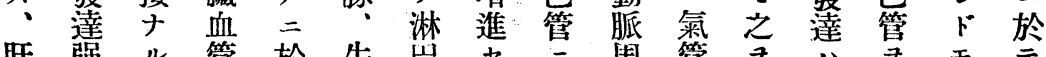

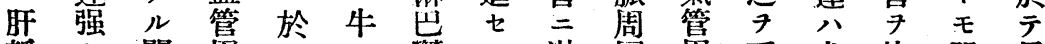

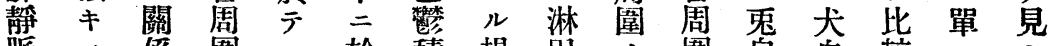
脈 八係圍八於積場巴藻自自較二

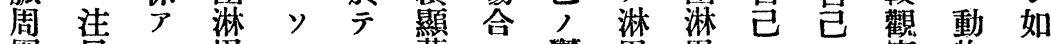

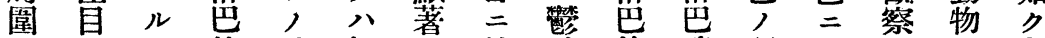

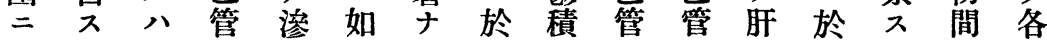




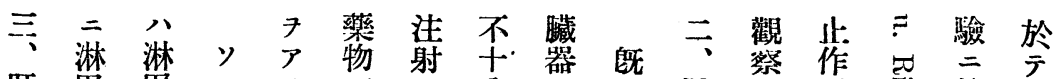

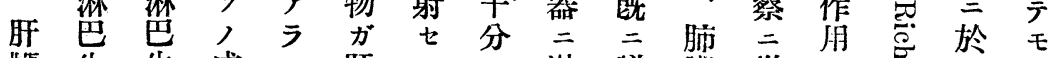

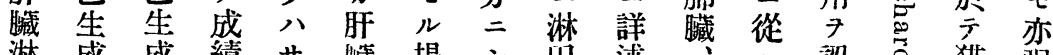

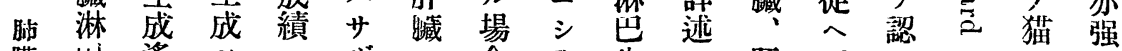

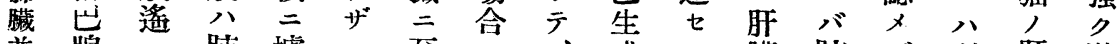

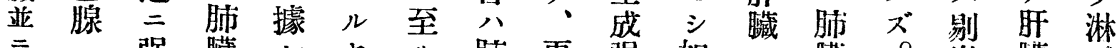

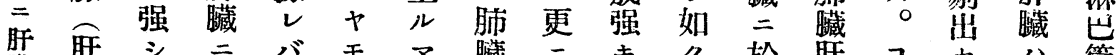

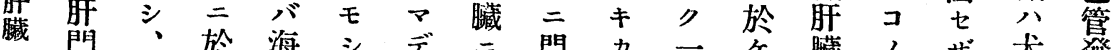
部 猫於海ジデ 門力 於部猫 テ 㩧レ二於静二動儿, コル。程達

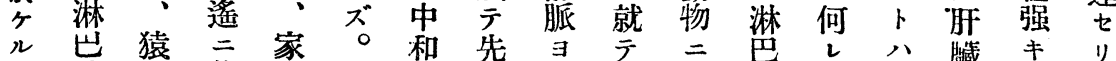

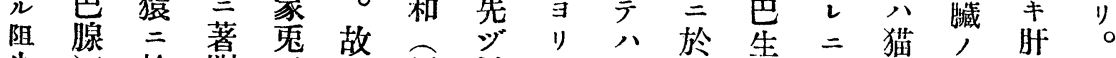

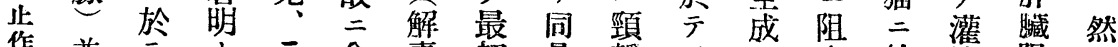
作並テナラ余毒初量靜り, 止於流阻

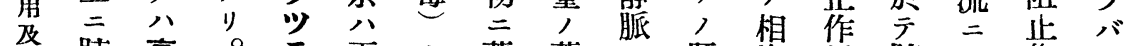

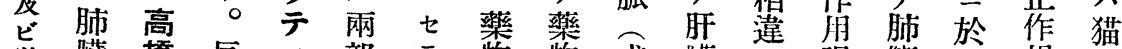

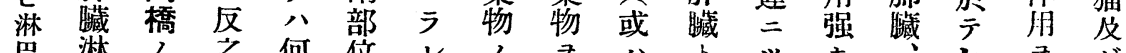

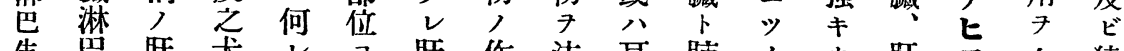

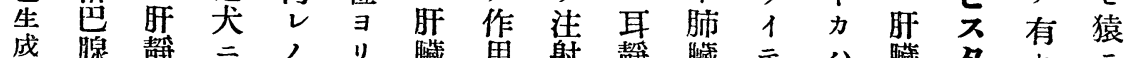

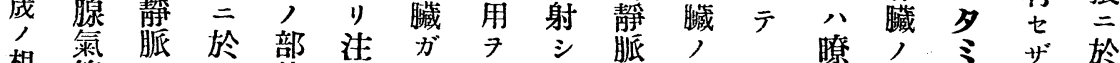

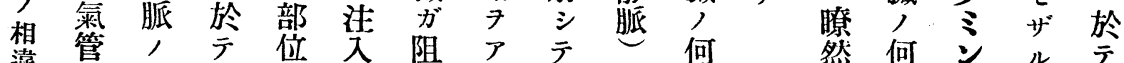

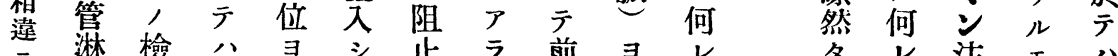
就檚紧 京㟲 $=$, 注詳用 三

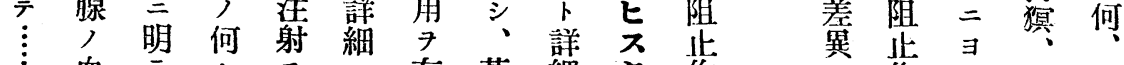
！血亏诗三有若細夕作

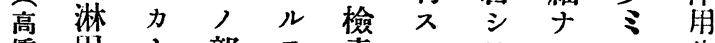
橋出ナ部毛索ルンツルシ 亚

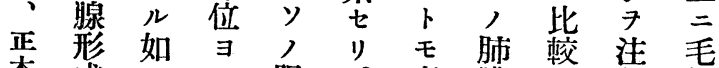

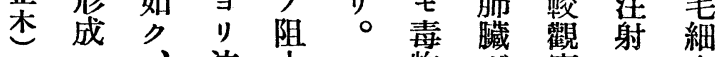
二:注歨物劣察 就 犬 射作, 阻子管 テ, ス用濃歨ナ肺漏 如 果作 ス 藏出 モ 並稀角 7 胙作

二 三 至 䆁 7 要臓用

六顯肝毛掏 ス强

七著䁍䋻 ラク比キ

$ナ$ 血 $v ア$ 何較只 差 於 管

買り出篇七施言

子, 作著ハバルス

認阻用明場頸,

$x$ 止 + 合猙 $i$ バ

范作 $\mathrm{L}$ 公脈二何

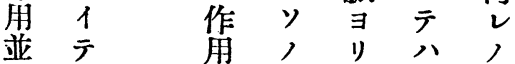

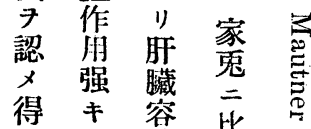

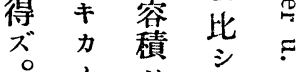
猿制佰著芯 定大蓄 於学七明， テ困 ズル 菜 主難 上阻 績 然 三云歨 據 ○公即用 心寻猫

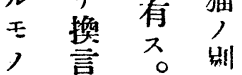
ナ ス 出 ル 然朋 モバル贜 、静 二 灌 余脈 导 流 


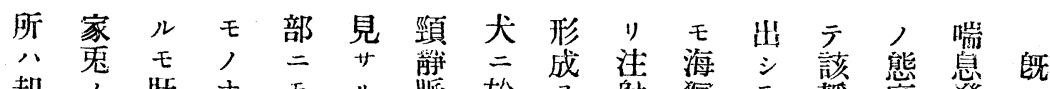

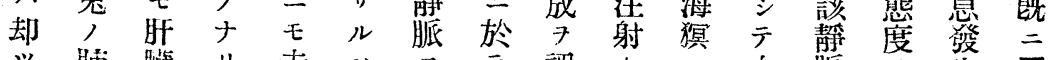

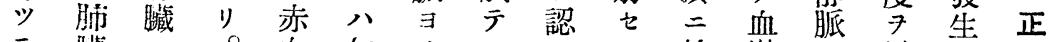

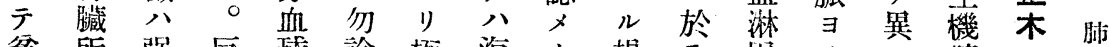

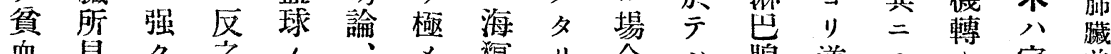

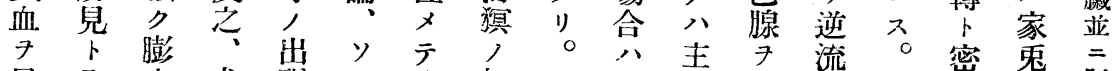
呈全大犬琴, 多如但

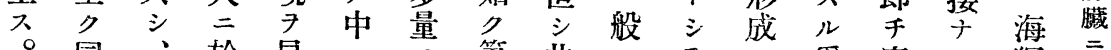

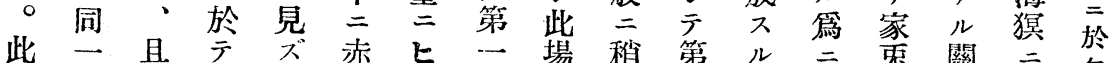

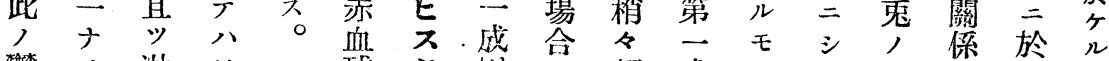

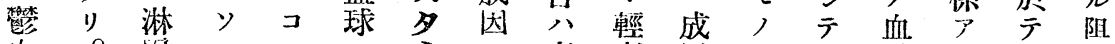

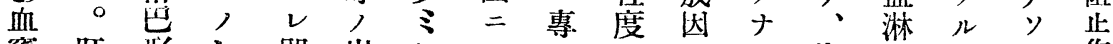

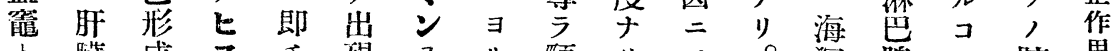

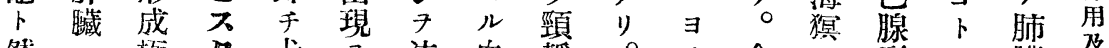

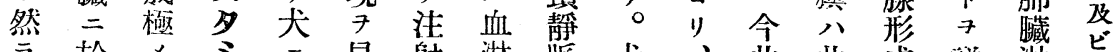

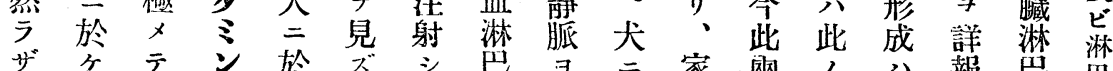
ル强作然

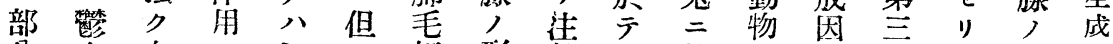

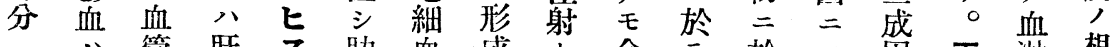

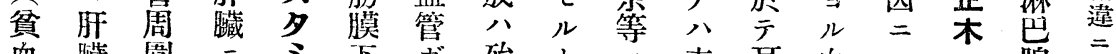

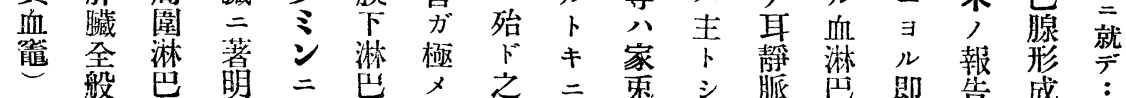

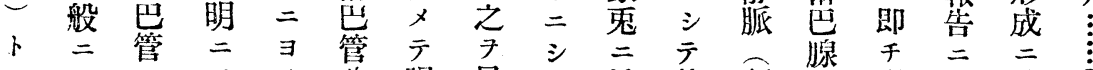

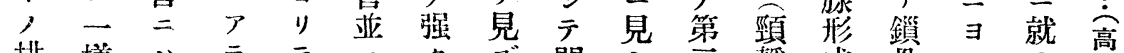
排㭼

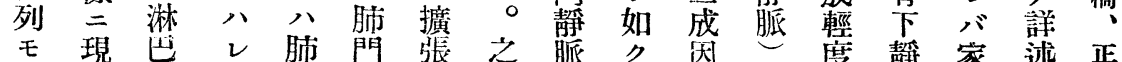

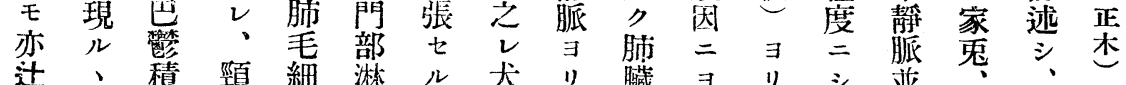

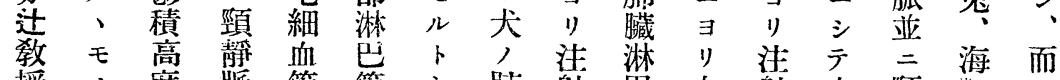

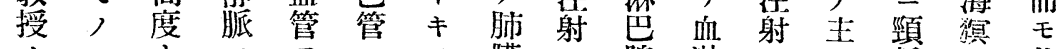
’ ナ $\exists \exists=モ$ 臟七腺淋七静分此

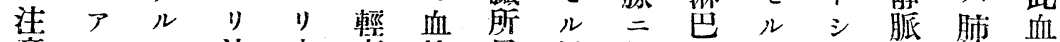

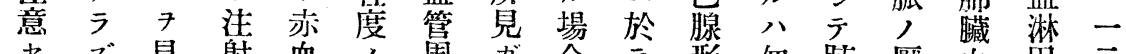

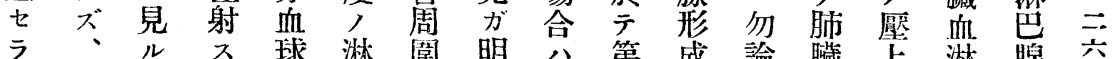
乙 或。

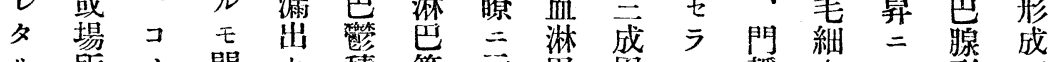

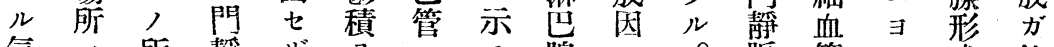

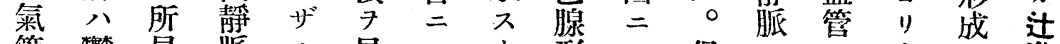

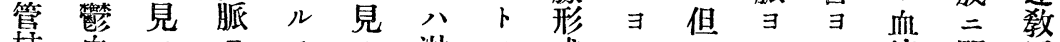
枝血 $ヨ コ$ 榃コ成ル亦りり液關授

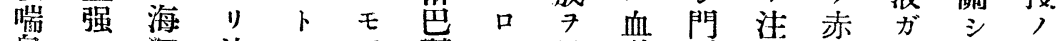

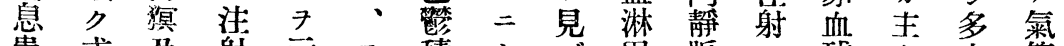
患彧 䓪 


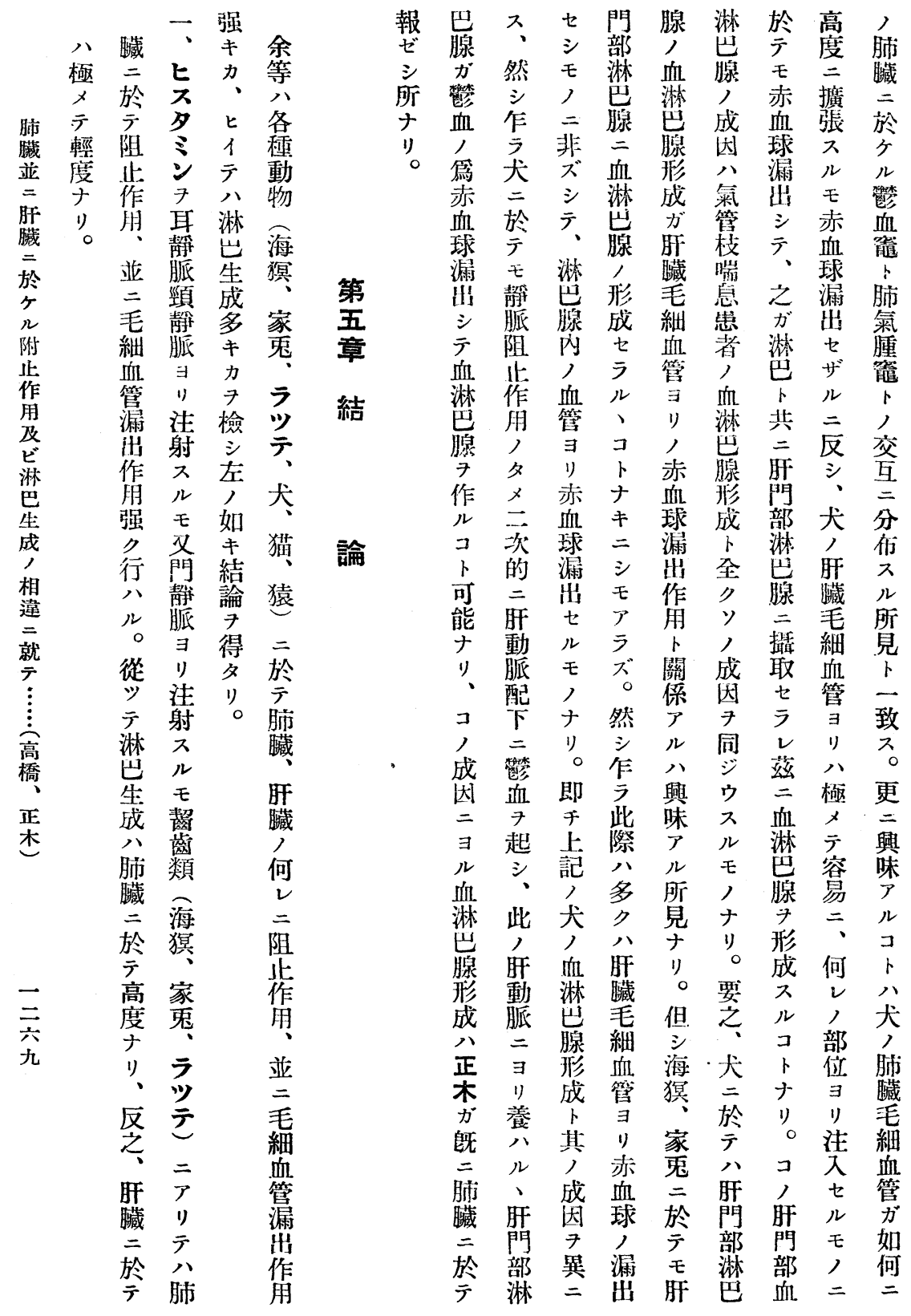




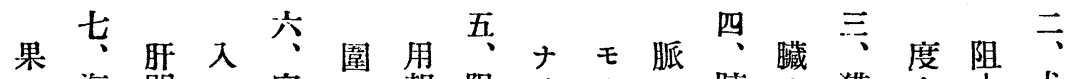

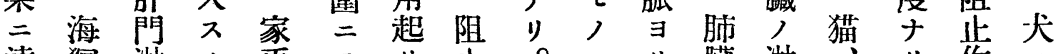

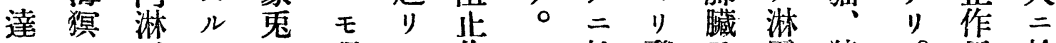

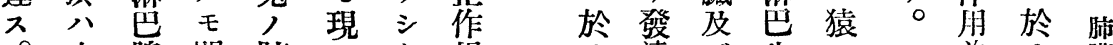

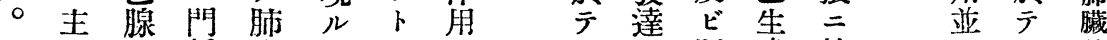
反卜三靜臟。市强旰成於二八亚

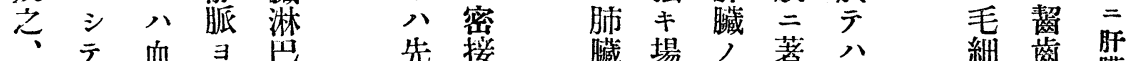

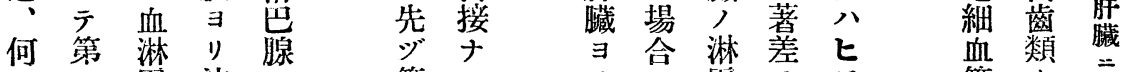

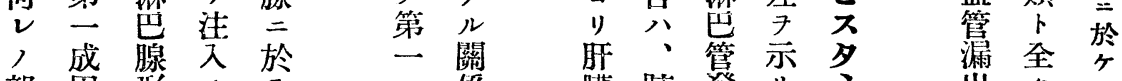

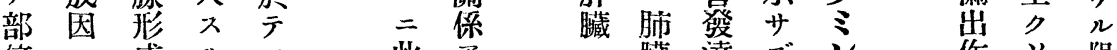
位二成ルハ此ア分臟達ズン 作ソ阻 $\exists \exists 7$ 主 リル見共卜 注 血 ズ 三 射淋、現 テ 总出少少第 毛䄸 ク但成 肝成王 严因 門 七第 淋亏後寻

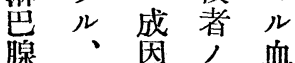
等此三洼淋 八場 $\exists$ 射笆 血合 , 腺 淋王場形 巴七, 合成 腺 入八公 子夕之稍

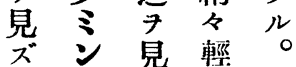
何梠摩 何。索主 新不 部及六作

售何㫐

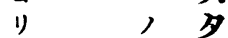

清部 今

射

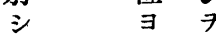

テ

モ 注静

同射脈

樣 ス

結兵注

血

管 淋

周焉 ) モ 血 , 管 二 周 淋 圍

藮强 1) 、發

輕 達 度 七 ナル ルモ r)

キ

八思

動

胍ル

圍 從

$=\frac{6}{3}$

强 夕

度

ル

卜 $\exists$

キ リ

ㄷ

靜阻

辳 歨

周 作
於淋少、 7

于飽阻此頸

淋管止, 䝑

巴, 作所脈

管發朋見 $\exists$

發達卜分り

澾妿密高注

强肝葌橋射

シ 塤 ナ, ス

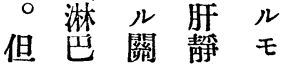

管 係脈 門

㠿發有比脈

所達 シ 粒

見寻・解り

八 換 剖 注

各强言學 射

動 ク ス 的 ス

物、乙檢儿

間反バ索モ

差之肺參笖

韭橗䁃照

非静、 : 罊

ズ脈肝テ埕

シ 无臟容類

テ肺 $尹$ 易二

、靜比二於

同脈較首

一 $三$ 肯 見

動りテシ シ

物强肺门如

二”静儿口

於發脈所肺

タ薘氒ナ臓

差ル静。朋
用, 歨

强趣莋

行暴茎

八二 淋

ル

從 不生

多相

志相

杷 7 就

生 頸 就

成 靜

八脈

肝 $\exists$ 高

贜 リ橋

二 注

於 射 正

テ 李

高ル

度

》) 門

、靜

反脈三

肺

臟 射

$=\pi$

於 ル

广元

八旰

極 臓

于 於

輕 


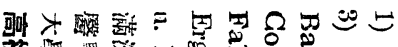

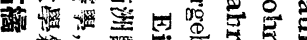

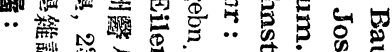

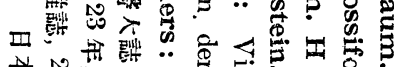

肺

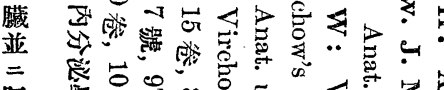

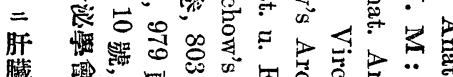

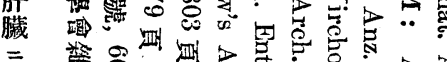

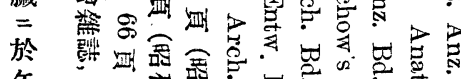

ル

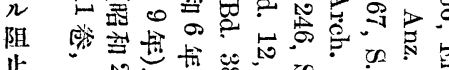

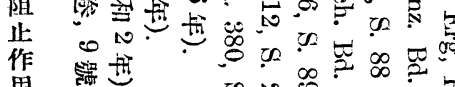

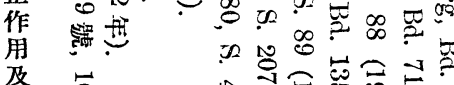

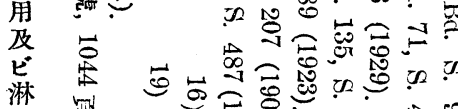

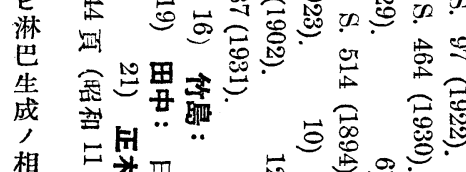

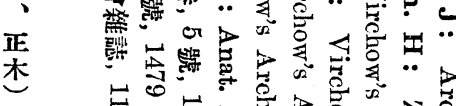

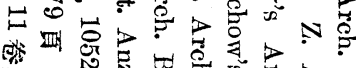

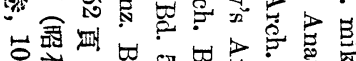

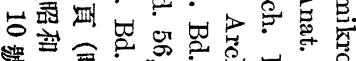

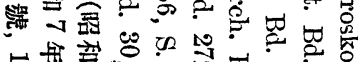

=

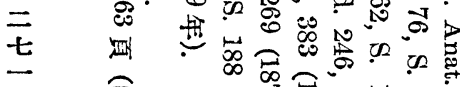

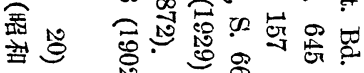

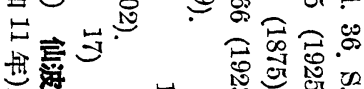

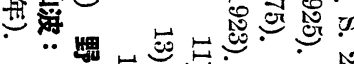

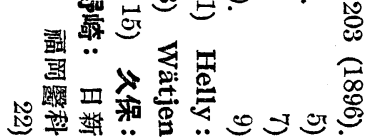

十家此九テ コ血

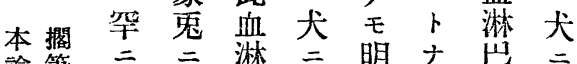
交筆石於等於ナり腺於 人臨 ゙多腺テリ・形テ 淛ミテ八人。此成八 旨終, 第肝七事 $七$ 頸

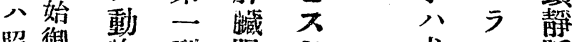
照御 物 型阻多犬脈

十篤 二 年守於血作 $ン$ 於然り

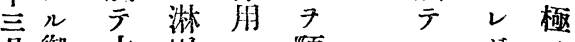

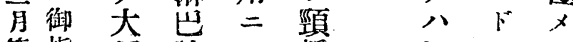
第指看腺 $\exists$ 静 七モう 怸導環形り眽家大

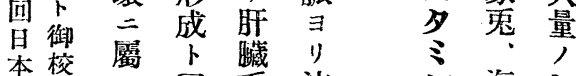
丙閶 分 $\Rightarrow$ 㧼細射 $\neq$ 猽 如, 夕 何場 尽 二 合 $ン$ 大 $\mathrm{r} 7$ 量 異 注 出脈㴬 シ 1 シ モ注 $\overline{~ 八 ~}$ , 射 モ 決 キ ナ ス 肺 シ 家 ルル 臟テ鬼 コ毛第三 居綃第於

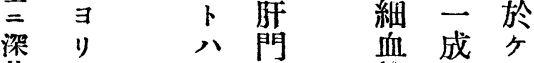
甚 血 部管因ル 于淋, 淋今 二 如

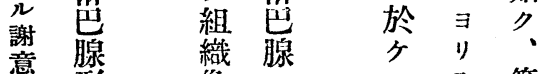
表型 , 




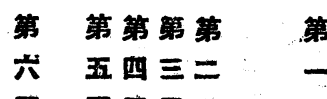

圖圖圖圖圖江圆

…䍡

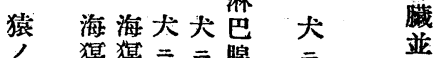

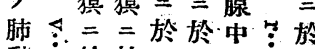

動於於ヶヶ, 於胙 脈强ヶケル儿淋血儿坿 贜 士勥几儿䏦助巴血淋

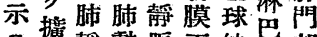

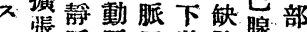
紫脈脈周淋除腺血 頚七周周園巴七淋 静少園園淋管几ヒ巴 脈小淋淋巴, 部吅腺 当肺巴巴間淋分资

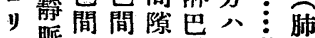
七脈隙隙及殹淋淋静 ス八、ビ 樍巴巴服

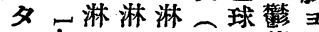

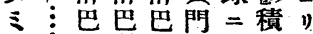

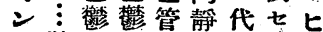
注肺程積, 脈 ソ兀 射靜 一淋 $\exists$ 淋夕

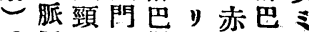

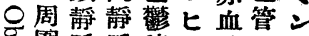

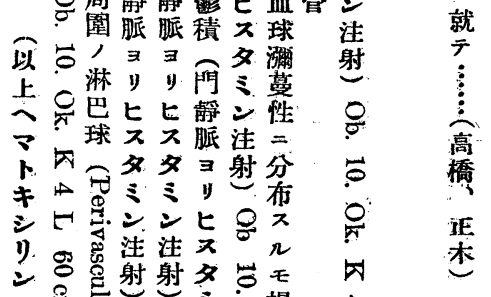

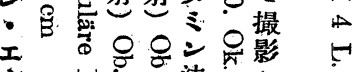

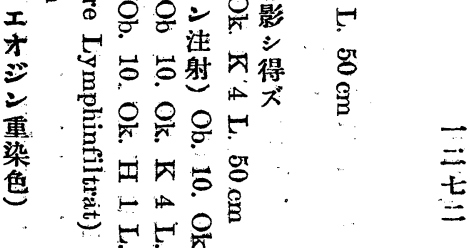
$+88$

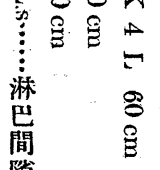


Fig. 1.

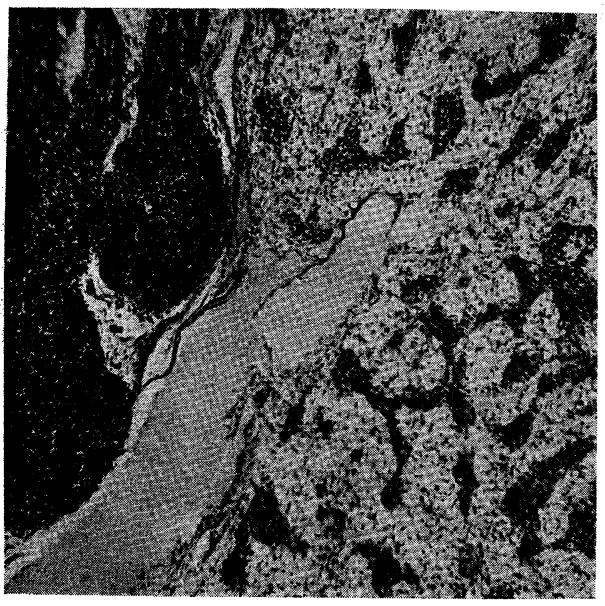

Fig. 3.

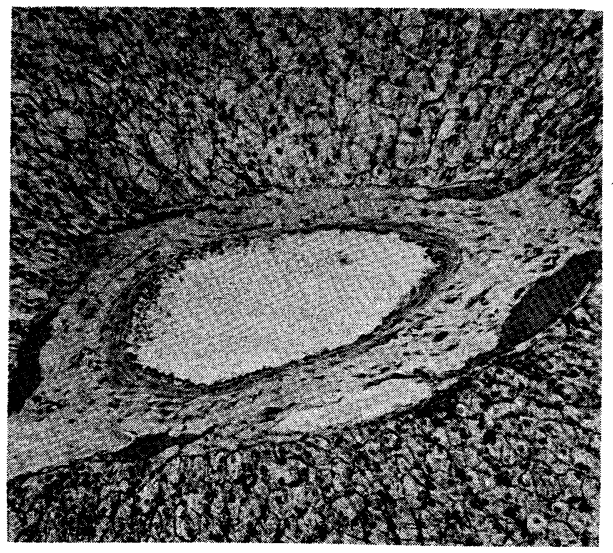

Fig. 5.

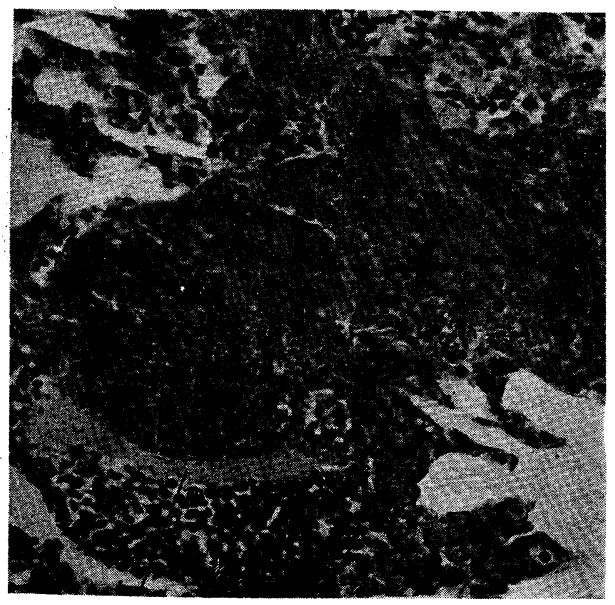

Fig. 2.

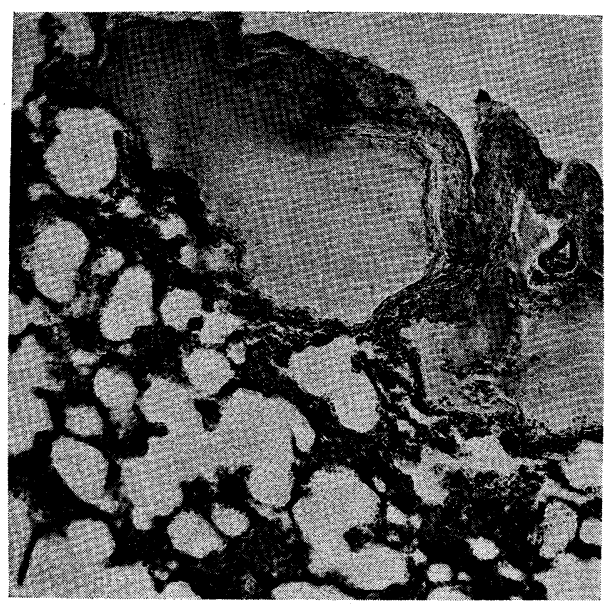

高

橋

俉

正

木

矛侖

之े

附

司

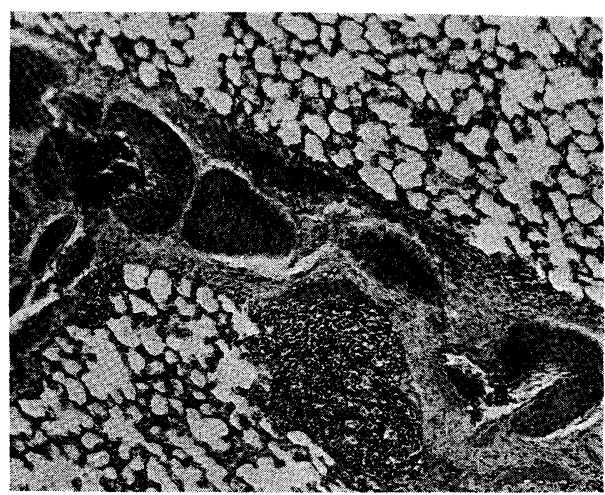

Fig. 6.

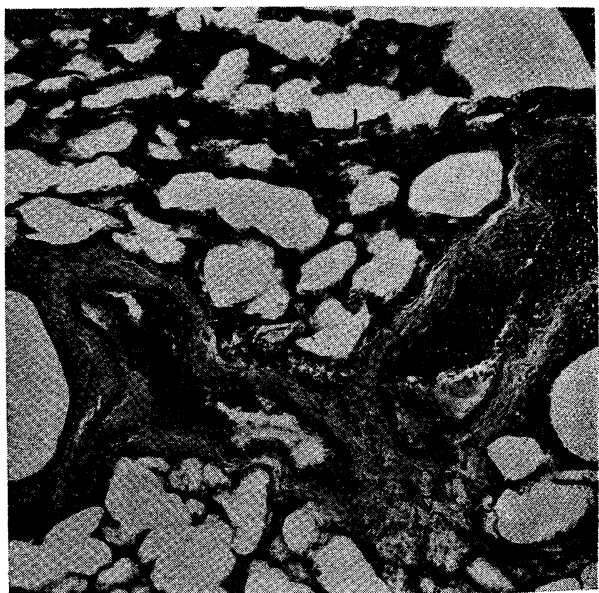




\title{
Über den Unterschied der Lymphbildung zwischen Leber uud Lunge bei der Histamininjektion bei verschiedenen Tieren.
}

\section{Anhang: Über die Blutlymphdrüsenbildung an den Lymphdrüsen des Leberhilus beim Hunde.}

\author{
Von \\ Dr. M. Takahashi u. N. Masaki \\ (Aus der l. Med. Kaiserl. Univers. zu Kyoto in Japan \\ Direktor: Prof. Dr. K. Tsuji)
}

Wir untersuchten histologisch bei verschiedenen Tieren (Meerschweinchen, Kaninchen, Ratte, Hund, Katze und Affe) den Unterschied der Lymphbildung zwischen Leber und Lunge bei der intravenösen Histamininjektion. (Einer von uns, N. Masaki, hat bereits bei Kaninchen und Meerschweinchen Blutlymphdrüsenbildung an den intratboracalen thoracobronchialen Lymphdrüsen gefunden. Ferner fanden wir die Blutlymphdrüsenbildung auch beim Hunde, und zwar an den Lymphdrüsen des Leberbilus.)

Unsere Resultate waren wie folgt:

1) Bei den Nagetieren ist die Vermehrung der Lymphbildung bei der intravenösen Histamininjektion (sowohl in die $\mathrm{V}$. jugularis als auch in die $V$. portae) in der Lunge stärker als in der Leber.

2) Beim Hunde ist die Zunahme der Lymphbildung bei der intravenösen Histamininjektion (sowohl in die V. jugularis als auch in die $\mathrm{V}$. portae) in der Leber stärker als in der Lunge.

3) Beim dem Affen und der Katze ist der Unterschied zwischen Leber und Lunge hinsichtlich der Lymphbildung nicht so deutlich wie bei dem Nagetiere und dem Hunde.

4) Die Entwicklung der Lymphgefässe, besonders der perivasculären Lymphgefässe in der Lunge und Leber, steht bei manchen 
Tieren mit der Sperrwirkung der V. pulmonalis und V. hepatica in engstem Zusammenhang.

5) Zur Blutlymphdrüsenbildung kommt es beim Kaninchen und Meerschweinchen bei der intravenësen Histamininjektion (sowohl in die Ohrvenen als auch in die V. portae) stets an den Lymphdrüsen der Lunge (thoracheobronchiale Lymphdrüse), nicht aber an denen des Leberhilus.

6) Die Blutlymphdrüsen an den Lungenlymphdrüsen beim Kaninchen bei der Histaminjektion gehören nach Masaki zu dem III. Typus, die an denen beim Meerschweinchen zu dem ersten Typus, worüber Masaki schon in Folia endocrinologica Japonica 1937 (Bd. XI Heft 10) ausführlich berichtet hat.

7) Beim Hunde bilden sich die Blutlymphdrüsen des III. Typus bei der intravenösen Injektion einer grossen Histaminmenge in die V. jugularis, niemals aber Blutlymphdrüsen des I. Typus; selbst nicht bei der intravenösen Injektion einer sehr grossen Histaminmenge in die V. Jugularis, weil bei diesem Tiere die Erythrocyten aus den durch Histamin stark dilatierten Iúngenkapillaren in die Alveolarlumen und die Alveolarsepten nicht austreten. (Siehe Folia endocrinologica jap. 1936 Bd. XI, Heft 10).

8) Beim Hunde treten die Blutlymphdrüsen bei der Histamininjektion sowohl in die Vena jugularis als auch in die v. portae stets an den Lymphdrüsen des Leberhilus auf.

9) Die Blutlymphdrüsen bilden sich an den Lymphdrüsen des Leberhilus, wenn auch nur selten, durch das Austreten der Erythrocyten aus dem stark dilatierten Blutgefässe (A. hepatica) in die Lymphdrüsen des Leberhilus.

(Autoreferat.) 